Article

\title{
Ghanaian SMEs Amidst the COVID-19 Pandemic: Evaluating the Influence of Entrepreneurial Orientation
}

\author{
Zhiwen Li ${ }^{1}$, Oswin Aganda Anaba ${ }^{1,2, *}$, Zhiqiang Ma ${ }^{1}$ and Mingxing $\mathrm{Li}^{1, *}$ \\ 1 School of Management, Jiangsu University, 301 Xuefu Road, Zhenjiang 212013, China; \\ zhiwenli@mail.ujs.edu.cn (Z.L.); mzq@ujs.edu.cn (Z.M.) \\ 2 School of Applied Science and Arts, Bolgatanga Technical University, Sumbrungu, Bolgatanga 233-72, Ghana \\ * Correspondence: oswin.anaba@bpoly.edu.gh or oswinaganda@yahoo.com (O.A.A.); \\ mingxingli6@163.com (M.L.)
}

check for

updates

Citation: Li, Z.; Anaba, O.A.; Ma, Z.; Li, M. Ghanaian SMEs Amidst the COVID-19 Pandemic: Evaluating the Influence of Entrepreneurial Orientation. Sustainability 2021, 13, 1131. https://doi.org/10.3390/ su13031131

Received: 26 November 2020

Accepted: 19 January 2021

Published: 22 January 2021

Publisher's Note: MDPI stays neutral with regard to jurisdictional claims in published maps and institutional affiliations.

Copyright: (c) 2021 by the authors. Licensee MDPI, Basel, Switzerland. This article is an open access article distributed under the terms and conditions of the Creative Commons Attribution (CC BY) license (https:// creativecommons.org/licenses/by/ $4.0 /)$.

\begin{abstract}
Entrepreneurial orientation has recently been touted as a tool for solving enterprise failures in emerged and emerging economies especially during and after an epidemic. This study aims at understanding the impact of entrepreneurial orientation on enterprise performance in the Ghanaian food processing industry by assessing the mediating effects of innovation types and intellectual property. Data were collected from 702 owners/managers in the food processing industry via survey questionnaires. The data were analyzed using the partial least squares structural equation modeling (PLS-SEM) to test the hypothesis via the Smart PLS software. The findings show that entrepreneurial orientation, innovation types, and intellectual property positively and significantly influenced enterprise performance. Furthermore, the results indicated that the mediation effects of innovation types and intellectual property were full and partial, respectively. Useful policy implications are further proposed and discussed based on the study results.
\end{abstract}

Keywords: COVID-19; entrepreneurial orientation; innovation types; intellectual property; enterprise performance; SMEs; Ghanaian food processing industry

\section{Introduction}

By the end of 2019, the world was hit by a novel contagious virus with human-tohuman transmission [1], which is now officially called "COVID-19" [2]. Due to its fast spread to many countries, it was termed by the World Health Organization (WHO) as a global pandemic. Nations all over the globe have initiated mechanisms to mitigate the spread of the virus by way of lockdown. This lockdown due to COVID-19 has severe bearings on economic and social activities. Especially, this lockdown has negative effects on Small and Medium Enterprises (SMEs). In this context, how to keep the sustainability of SMEs becomes a great concern for all countries worldwide.

There has been a forced closure of many SME businesses due to the COVID-19 pandemic outburst, which has led to a unique interruption of business in most industry sectors, especially the manufacturing sector [3]. Many SMEs in the manufacturing sector are confronted with short-term issues, such as those related to health and safety, the labor force, cash in-flow, demands from the consumers, sales, and marketing. There is, however, not an assured promising future if these issues of a pandemic situation have been successfully managed. This is because once a pandemic situation, or any other situation that has the tendency to disrupt businesses, is over, there will arise a very different world of business compared to the one before the pandemic. Many SMEs, especially in the manufacturing sector, no longer exist.

The relevance of SMEs to the health of any financial system cannot be exaggerated. There have been numerous studies, both in advanced and emerging countries, about the main progressive role that SMEs play in every economy [4-7]. SMEs perform well by ensuring that teeming job pursuers are employed, front as an avenue for novelty and offer 
returns in the form of tax to the government; hence, the reason it has been branded as a panacea for economic growth [8].

According to Abor and Quartey (2010), in Ghana, the SME sector is the main structure of businesses accounting for close to $92 \%$ of enterprises in the economy. Besides, in 2018, it was projected that SMEs added to Ghana's Gross Domestic Product (GDP) by an estimated $70 \%$ contribution, which translated to about $90 \%$ of operational businesses. The sector is also said to provide close to $85 \%$ of jobs in Ghana $[8,9]$.

Ghana's business setting is reinforced by an inspiring economic growth and sturdy innovation in the business sector. The work environment is an exceptional mixture of officially and traditional Ghanaian culture. Many other West African countries, especially the Anglophone countries, also exhibit such business setting as can be found in Ghana.

The Ghanaian economy is traditionally divided into three sectors; namely, agricultural sector, service sector, and the industrial sector [10]. With a growth rate of 24.3 per cent of GDP in 2016, the manufacturing sector still stands in its typical second place among the five industrial subsectors of Ghana [11]. About $9 \%$ of Ghana's GDP consist of the manufacturing sector, which has created over 250,000 jobs for the citizenry [12]. The number of registered enterprises is said to be around 25,000, although more than $80 \%$ of them are SMEs.

The manufacturing sector of Ghana ceaselessly plays a reputable function in the Ghanaian economy. The sector encompasses numerous subsectors, such as the food processing industry, agro-processing, and so on. The food processing industry is one of the most important industries that meet the basic needs of people during the pandemic period. It is, however, one of the vulnerable industries that are affected by the pandemic. Many infected COVID-19 cases were found in the food processing factories around the world because of infected materials, bad working environment, and so on. This brings uncertainty to the Ghanaian food processing industry, which has been struggling in recent times [13,14]. The food processing industry is historically one of the oldest in Ghana. The industry is quite easy to enter but also has a high exit rate. It is mostly made up of micro- and small-scale enterprises that mostly operate with little capital, engaged in low better-quality food processing, and use simple tools. For the characteristics stated above, the food processing industry was chosen for this research.

Notwithstanding the recognized SME significance to the Ghanaian economy, they are confronted with problems that smother their growth prospects especially during and after this COVID-19 pandemic [15-18]. A number of such innumerable challenges emanate from the lockdown, making people stay at home and not be able to buy or sell any products, insufficient finance, deficient marketing expertise, harsh regulations from government, competition from overseas firms, lack of innovation, and substantially more. The steady decline in growth of some Ghanaian SMEs is, therefore, a result of these challenges $[19,20]$.

In every enterprise, it is the hope that the enterprise maintains a sustained growth as the years goes by, whether during smooth or turbulent times, but the manner in which some business owners or managers pursue these growth prospects will demonstrate whether the enterprise will collapse or grow during periods such as a natural disaster. In addition, the COVID-19 pandemic was not an expected one; hence, most business owners and managers could not and are not able to bring out strategies that would offer sustainability of their businesses during and after these trying times.

According to extant literature, entrepreneurial orientation has on many occasions been seen as one of the strategies for business success in a crisis situation like the Ebola virus, SARS, and the other contagious diseases that confronted the world at some time. Entrepreneurial orientation not only gives competitive advantages to a business but gives a form of sustainable growth [21-26].

This study, therefore, evaluates the influence of Entrepreneurial Orientation (EO) as a panacea to a sustainable SME growth before, during, and after a pandemic [27]. It is interesting to note that most literature in the field of SME growth and failures have only considered the relationship between one independent variable and how it influences SME growth or enterprise performance [28]. The determinative aspect and locus of this 
study is the influence of EO. Studies have revealed that EO has been used as an indicator in many researched works in relation to Enterprise Performance (EP). Extant studies have indicated the importance of EO pertaining to EP $[29,30]$. Other works have also proved the negative influence of EO in respect to EP [31]. In line with this, managers and owners of these enterprises are expected to devise a strategy to strengthen the relationship between EO and EP, since that could enhance the progressive survival of these enterprises (the food processing industry) before, during, and after the COVID-19 pandemic [32,33]. Intellectuals are, therefore, handicapped in investigating the potential mediator(s) that strengthen the relationship between EO and EP. Agreeing with this claim, the argument is that owners or managers with EO may influence the growth of enterprises since they possess entrepreneurial knowledge and skills in their daily business activities [34].

Extant literature has been limited in examining the interactive substance that influence the relationship between $\mathrm{EO}$ and $\mathrm{EP}$, hence, in a quest to bridge the gap that exist in literature and to contribute to academic knowledge on the relationship between $\mathrm{EO}$ and $\mathrm{EP}$, this paper, thus, explores the mediating influences of Innovation Types (IT) and Intellectual Property (IP) in the influence of Entrepreneurial Orientation on Enterprise Performance in the Ghanaian food processing industry.

Hence, this study is guided by the following questions; does entrepreneurial orientation influence enterprise performance during a pandemic situation, and how does the mediating effects of innovation types and intellectual property influence the sustainability of SMEs during a pandemic?

The hypothesis that are developed and results findings, via the use of the structural equation model (SEM), of this study, will go a long way to inform owners and managers of SMEs in all sectors on the influence EO will have on enterprises before, during, and after an unexpected negative event that threatens the sustainable growth of their businesses.

\section{Materials}

\subsection{Theoretical Framework}

The framework of this current study is founded on the theory of entrepreneurial orientation. The last two to three decades have seen an extensive discussion of EO theory in management literature [35]. EO, as defined by Lumpkin and Dess [36], is the processes, practices, and managerial activities leading to fresh-entry, consequently, classifying the five significant measures that make up EO as the tendency to perform autonomously, ready to innovate, take calculated risks, the ability of being aggressive on competitors, and be proactive in taking advantage of marketplace opportunities.

Historically, EO research has primarily focused on firm-level entrepreneurship [37]. According to Kuratko and Morris [38], the theory of EO tracks back to the literature of strategy-making process [39] and has come to be noticeable in both strategic management and entrepreneurship literature. Remarkably, Covin and Slevin [40] and prior works by Miller [41] are the most lengthily used operationalization of EO. Diverse expressions or tags, for instance, entrepreneurial mode [39], entrepreneurial style [39], entrepreneurial posture Covin and Slevin [40], strategic posture [42], corporate entrepreneurship [43], and entrepreneurial orientation [36], have all arose in deliberating this enterprise-level conduct in entrepreneurship.

Nevertheless, this study adopts the entrepreneurial orientation theory of Lumpkin and Dess, since it is one of the most widely applied constructs.

The next section below will discuss the relationship between the various variables that could potentially influence enterprise performance in the Ghanaian food processing industry.

\subsection{Hypothesis Development}

2.2.1. Entrepreneurial Orientation and Enterprise Performance

A dispute regarding the complex relationship between EO and EP has recently emerged. There has been a lot of literature by some reputable scholars on the positive rela- 
tionship between EO and EP [27,44,45], while other scholars like Moreno and Casillas [31] contend that the relationship between EO and EP is negative. Nevertheless, it has largely been acknowledged, since the emergence of the concept of EO that a positive link between EO and EP exists [41,46-48].

EO is, thus, essential for enterprises to ascertain novel entrepreneurial opportunities and vie with other business entities [49]. In line with results from earlier research on EO, it is expected that all the measures of EO as recommended by Lumpkin and Dess [36], will positively and significantly influence EP. Hence, this study assumes that EO has a direct and positive effect on EP; thus:

Hypothesis 1 (H1). There is a positive and significant relationship between EO and EP.

\subsubsection{Innovation Types and Enterprise Performance}

Innovation is the espousal of concepts or creativity that improves the products, processes, and procedures by increasing the significance, usefulness, and performance of the products and/or services. SMEs are perceived to be a vital force that can boost economic growth via the application of entrepreneurial philosophies and innovation [50]. The endurance of individual enterprises and the sources of competitive advantage that meets the changing demands of customers have been widely associated with innovation [51].

Previous studies of the link between IT and EP indicated mixed results, some positive performance [52-58], some negative, and some suggesting no relationship at all [59,60]. According to Rajapathirana and Hui [61], the type of innovation espoused can aid in the improvement of an enterprise's competitiveness with the definitive aim of increasing enterprise value. Innovation is all about new ways of studying and serving current markets, which ensures enterprises to deliver appropriate offers and yields greater avenues [62]. This study, therefore, argues that IT has a direct and positive effect on the performance of SMEs:

Hypothesis $\mathbf{2}$ (H2). There is a positive and significant relationship between IT and EP.

\subsubsection{Intellectual Property and Enterprise Performance}

The literature on intellectual property (IP) is sundry, and numerous different measures have been employed with the aim of capturing the effect of IP on the performance of SMEs. Some studies reveal that IP (patent) has no link with return on assets (ROA), sales growth, and market value, respectively [63,64], or that they associate negatively with ROA [65]. A number of other research articles have, on the other hand, found a significant and positive association between IP and sales, IP and market value, IP and stock returns [66,67].

A few of these academic scholars fixated their investigations on certain types of enterprises with the goal of refining the interpretation on the relationship between IP and SME performance $[68,69]$. Hence, we hypothesize that:

Hypothesis $\mathbf{3}$ (H3). There is a positive and significant relationship between IP and EP.

\subsubsection{Entrepreneurial Orientation and Intellectual Property}

An enterprise with an $\mathrm{EO}$ has the propensity to proactively locate prospects, invent, and take calculated risks [70]. An enterprise with an inclination towards the acquisition of IP is concerned with protecting and safeguarding privileges for an invention. An enterprise that does not acquire IP either have no funds to do so or sees little worth in acquiring it (e.g., since the changes in industry are so quick that IP acquisition is virtually an obsolete action) [71]. The hypothetical cornerstone between EO and the activities of IP is the tactical capitalization of innovation. Explicitly, an enterprise with an EO is involved in the creation of groundbreaking products, methods, and tactics, many of which could be patented, trademarked, etc. [72]. Similarly, an enterprise with an EO is agreed to be identifying, creating, measuring, and taking advantage of prospects [73]. A lot of those prospects should have a satisfactory degree of newness that provides IP contingencies. Finally, an enterprise with an EO takes rational but considered risks, i.e., its preparedness in making courageous decisions so as to attain strategic goals $[39,74]$. Enterprises with an EO have that desire to 
collate and guard their inventions by the way of trade secrets, patents, trademarks, and/or copyrights. Therefore, we hypothesize that:

Hypothesis 4 (H4). There is a positive and significant relationship between EO and IP.

\subsubsection{Entrepreneurial Orientation and Innovation Types}

Innovation has become not only a business strategy but also an unavoidable activity in the ultimate survival of enterprises, especially SMEs, in an uncertain atmosphere of business along with a highly competitive market and a constant change of technology and information [75]. Therefore, it is essential that enterprises take advantage of the opportunities given by a globalized market as well as knowing the preferences and needs required by the market so organizations develop new products or improve the existing ones needed by their clients and consumers, such that they can significantly increase their innovation activities and improve their competitive advantages [76].

EO is an enterprise-level strategic orientation, which entails an enterprise's behavior, strategy-making customs, and decision-making philosophies that are of an entrepreneurial character $[77,78]$. EO has in recent times turned out to be one of the most recognized and explored constructs in the entrepreneurship literature [35,79].

There have been several studies on the relationship between EO and IT [40,80-82]. Most preceding studies that have examined the link between EO and an enterprise's innovation, especially in espousing one of the types of innovation, all had positive and significant results [83-87]. Zhai, et al. [88] showed that the link between EO and IT was significantly positive. In view of extant literature, it can be claimed with assurance that innovation is an activity of EO, therefore, we hypothesize that:

Hypothesis $\mathbf{5}$ (H5). There is a positive and significant relationship between EO and IT.

\subsubsection{Innovation Types and Intellectual Property}

The best usage of IP tools will play a very vital part in decreasing risks involved with creativity and inventions, since the creator or inventor may be able earn adequate returns from their innovations [89]. IP performs a facilitating role by taking innovative technology to the open market and, simultaneously, plays a major role in enriching competitiveness in enterprises based on technology [90].

The outcome of a positive invention is a more competent way of undertaking things in majority of technology-based enterprises. It is necessary to note that if an enterprise wants to benefit from its novel ideas through innovation it must first treat its novel idea as a trade secret. It should be observed, therefore, that not all marketable innovative concept can or will be patented [91]; hence, the significance of treating novel concepts at their inception stage as a trade secret.

To stay competitive, empirical evidence posit that SMEs are more persuaded to adopt trade secrets instead of patents as a method of safeguarding their inventions [92]. High costs and difficulty in the patent system are key motives why SMEs run away from patents. A research conducted in Australia suggests that $44 \%$ of the enterprises adopts patents, whereas $74 \%$ adopts trade secrets as a way of safeguarding their novel ideas. The study further revealed that $35 \%$ of small enterprises with not more than 20 workers espoused patents, whereas $75 \%$ of enterprises with not less than 500 workers had their innovations patented $[93,94]$.

While IP-related costs and difficulty of the IP process may be seen to hinder innovation, predominantly in cash-strapped SMEs, in some cases it is also factual that if utilized strategically, IP can become a reliable source of new and higher revenue for SMEs. Based on this, we hypothesize that:

Hypothesis 6 (H6). There is a positive and significant relationship between IT and IP.

\subsubsection{Mediating Effects of IP in the Relationship between EO and EP}

The development of IP in the present open and international markets is nowadays perceived as a primary force instigating economic expansion and competitive advantage [95]. 
Managers, as a result, are more and more fixated on how to safeguard intellectual capital invented and confined within their enterprises to guarantee that the new knowledge provides the enterprises with strategic rewards [96]. IP is a mechanism available to managers of enterprises with the interest of codifying and guarding their enterprises' IP and deliver the strongest formula of IP safety within the granting establishment [97]. Managers have appreciated the strategic significance of IP since, as Dzenopoljac et al. [98] note, "there is a progressive use of the words patenting and strategy in the same phrase by executives".

Promoting effects of EO on EP have gotten some wide consideration, and indications of it were recommended by many prior researchers [99-101]. For the mediating effects in this relationship, there is still a lack of methodical and obvious interpretation about this problem, such as which variables can mediate or moderate EO and EP.

As an examination for the questions above, Covin and Slevin (1991) originally suggested a conceptual model concerning EO and EP, integrating mediating or moderating effects, which tends to be applied widely, not only to constitute the theoretical foundation of EO and performance, but also hypotheses formulation [36,44,102].

According to Zhang and Zhang [44], EO has a positive effect on EP, and network abilities can meaningfully mediate relationship between $\mathrm{EO}$ and the performance of businesses. Therefore, using IP as a mediating variable will improve the relationship between $\mathrm{EO}$ and EP. Thus, we hypothesize that:

Hypothesis 7 (H7). IP mediates the positive relationship between EO and EP.

\subsubsection{Mediating Effects of IT in the Relationship between EO and EP}

A study by Calisir, et al. [103] in Turkey concluded that IT is a significant mediator between enterprise processes and performance. Moreover, Avlonitis and Salavou [104] found that EO is a significant predictor to IT. The authors stated that EO among Greek SMEs is primarily mirrored through new product development, which embodies uniqueness, high level of innovativeness, proactive market leadership, and willingness to take the risk. Derived from a study by Hami, et al. [105] and Kee and Rahman [29], their findings yielded consistent results from literature, as IT is proven to act as a mediator to improve performance among manufacturing firms in Malaysia. The significant mediation effect of IT results in an improved method of product development. Nevertheless, findings on the direct link between IT and performance also produced mixed results and remain unresolved, as some studies by $[106,107]$ found no relationship between these two variables. Thus, based on the above discussions, IT is justified as a potential variable to be studied as a mediator towards EP and deserves more research in this manner considering the weight of mediator effects on EO and performance relationship. We, therefore, hypothesize that:

Hypothesis 8 (H8). IT mediates the positive relationship between EO and EP.

\subsubsection{Mediating Effects of IP in the Relationship between IT and EP}

There has been very little to no research on the mediating role of IP between IT and EP. However, many researchers such as Davila, et al. [108], Joe and Fiona [109], Kronthaler [110], and Shih [59] amongst others have clearly revealed that businesses and management operations have benefited from the contributions from innovative enterprises. The classifying of innovation as incremental, radical, disruptive, and/or architectural is among the most rooted in the literature.

According to de Zubielqui, et al. [111], Zhu, et al. [112], Ramadani, et al. [113], and Dabić, et al. [114], IT is positively related to EP.

Other scholars have also found a positively significant relationship between IP and EP [115-119].

From the above findings, we posit that using IP as a mediator can improve the relationship between IT and EP. We, therefore, hypothesize that:

Hypothesis 9 (H9). IP mediates the positive relationship between IT and EP. 


\section{Methods}

\subsection{Sample Size and Process}

The current study's target population was SMEs operating in the formal sector (certified with the National Board for Small Scale Industries (NBSSI) or the Association of Ghana Industries (AGI)) of Ghana's food processing industry. Primary data were attained via the administration of a structured questionnaire. The data were collected between February and May 2020. After obtaining approval from owners and manager of the various SMEs in the various 16 different regions of Ghana, respondents were then contacted to partake in the survey. The structured questionnaires were disseminated among $(N=840)$ owners, managers, and high officials of enterprises through a nonprobability sampling method and privacy of the responses were guaranteed. Samples with doubtful responses and missing data values were expunged. The total response figure was $84 \%(N=702)$. The high response rate is largely due to the lockdown during the COVID-19 pandemic, which enabled participants to have more time to answer the questions.

\subsection{Measures}

The measurement constructs for the study were all computed on a 5-point Likert-scale ( 1 , strongly disagree; 2 , disagree; 3 , neither agree nor disagree; 4 , agree; and 5 , strongly agree). The quantification of each construct is detailed as follows:

EO was quantified via a 35-item entrepreneurial scale refined by Alembummah [120] and Venter [121], and includes: "Our firm regularly introduces new services/products/ processes" and "Our firm is continually pursuing new opportunities". IT was quantified by a 28-item innovation scale advanced by Damanpour [122], Moch and Pondy [123], Dewar and Dutton [124], and Collins, et al. [125], and includes: "Our firm invest a lot of resources in research and development (R\&D)" and "Our firm is based on what people do, not what they say they do". IP was measured by a 28 -item intellectual property developed by Linton [126]. Two of the items represented under intellectual property comprise: "Our firm has its own unique trademark and acquiring patents does not have any impact on the growth of our firm." EP was calculated by a 20-item enterprise growth scale developed by Venter (2014), Alembummah (2015), Wu [127], and Akrofi [128]. Items consist of: "Our firm has experienced growth in market share over the past few years" and "Our firm have experienced growth in profit over the past few years". Indicators for the measures for the study are displayed in Table A1.

\subsection{Method of Analysis}

\subsubsection{Tools}

The partial least square equation modeling was used to measure the hypotheses of this current study via the use of the Smart-PLS software version 3.0 as illustrated in Figure 1 [129-131]. The reason for using the Smart-PLS software is because of the robustness it possesses in scrutinizing theoretical establishments and predictive applications; and also, the best model to use in this type of exploratory analysis [132].

The PLS applications, as posited by academicians, is founded on the choosing of cases with observations not more than 250 or 400, especially when there is less consistency in the model [133,134]. According to extant literature, Partial least square (PLS) is said to consist of two phases [135]. In phase one, the assessment of measurement models allows an academic investigator to survey the presence of interconnection between observed and latent variables, whereby phase two encompasses the evaluation of predictive enquiry of causal association among the variables of the study. 


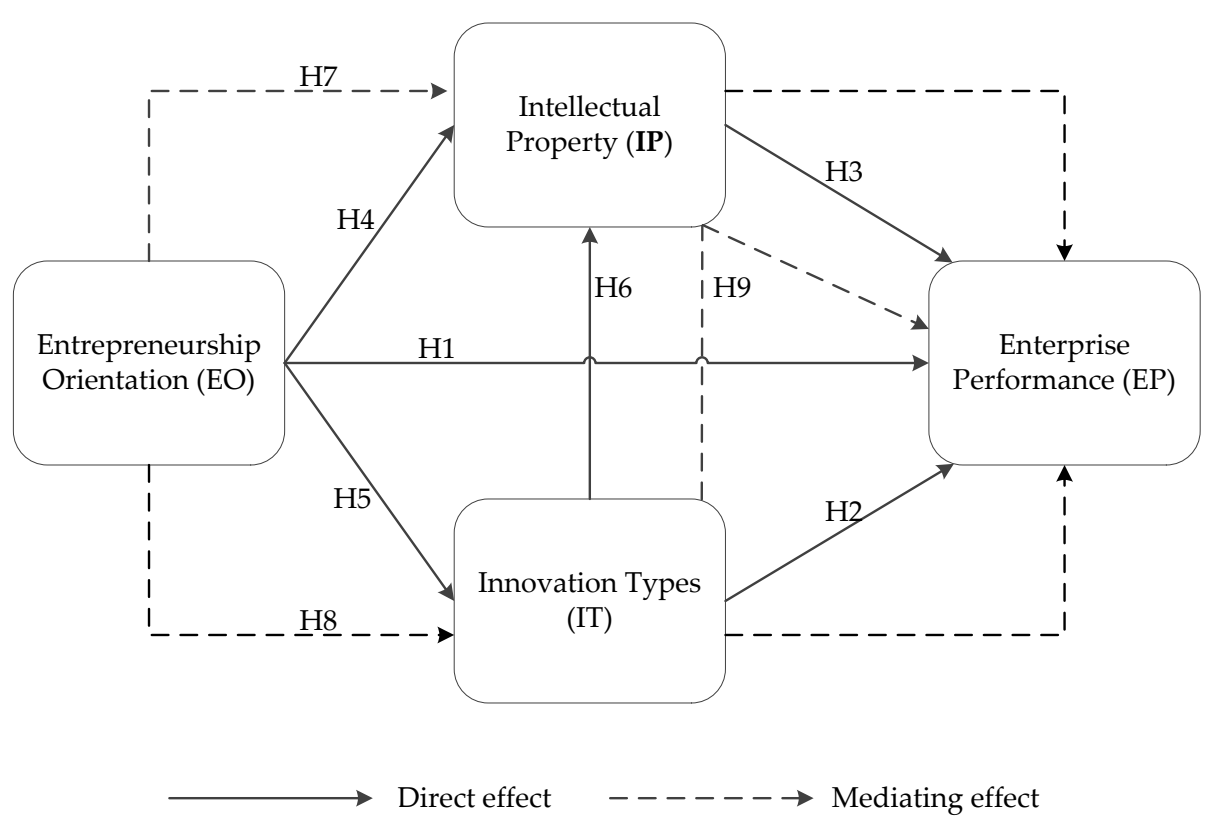

Figure 1. Conceptual framework with two mediating variables.

\subsubsection{Confirmatory Factor Analysis}

This study initially conducted an exploratory factor analysis (EFA) via SPSS version 23 to confirm the aptness of the data for factor analysis [136]. All the factor loadings with values less than 0.6 were removed due to poor factor loadings. A confirmatory factor analysis (CFA) was also performed using Smart-PLS version 3. This was done to establish whether the model is acceptable or not. In so doing, the study found that there exists some form of relationship between the observed and unobserved variables, which complement the model, and again elucidate the form by which different measure loads a given factor [137]. The structural equation modeling (SEM) was preferred for this study due to the fact that SEM is capable of alleviating measurement error issues in relationship research concerning latent variables.

\section{Results and Discussions}

\subsection{Demographic Information}

The demographic information consisted of the following: gender: 477 men (68\%) and 225 women (32\%). The ranges in ages of the respondents were from 21 to $65+$ years (Mean $=3.24, \mathrm{SD}=1.20)$. Academic credential: $12 \%(n=82)$ had no formal education, whereas $7 \%$ $(n=48)$ had only primary education, $13 \%(n=91)$ high/secondary school education, $18 \%(n=124)$ had some vocational training, $37 \%(n=265)$ had Higher National Diploma or Bachelor's degree, and 13\% $(n=92)$ had a postgraduate degree. Their positions were as follows: $70 \%(n=494)$ were general managers/owners, $17 \%(n=118)$ were marketing/sales managers, and $13 \%(n=89)$ were supervisors.

\subsection{Descriptive Statistics}

The study put into use four (4) constructs in the model as second-order reflective constructs (i.e., the entrepreneurial orientation, innovation types, intellectual property, and enterprise performance). The Cronbach alpha coefficient, factor loadings of the suconstructs of the main constructs, Eigenvalues, composite reliability (CR), percentage variance, and the average variance extracted are displayed in Table A3. For each of the factor loadings, the indicators surpassed the accepted threshold of 0.7 [138]. Results from Table A3 suggest that all constructs are reliable since, in the first phase of the study, the values for the Cronbach alpha coefficient and composite reliability are higher than the threshold of 0.7. The average variance extracted (AVE) values retrieved from the factor analysis agree to 
the threshold of 0.5 and above, demonstrating that at best $50 \%$ of the variance in indicators has been calculated [139].

\subsection{Model Fit Calculation}

A model fit calculation was performed in this study. One condition anticipated to note under structural equation modelling (SEM) technique is the model structure [137]. The general fitness of the model is measured using the outcomes of the measurement model.

It is established that each observed latent variable correlate and agrees with the conditions of reliability and validity adequately. Against this, the model fit test was carefully observed given consideration to a range of indices tests, such as the chi-square test $=2622.54, \mathrm{NFI}=0.931$, SRMR $=0.083$, consistent with earlier studies [140]. Table 1 presents the model fit measures.

Table 1. Model fit for direct effect analysis.

\begin{tabular}{cccccc}
\hline Model & SRMR & d_ULS & d_G & Chi-Square & NFI \\
\hline Saturated Model & 0.083 & 1.727 & 0.714 & 2622.54 & 0.931 \\
\hline
\end{tabular}

In a quest to ensure the adequacy of the model, consideration was given to the cutoff criteria reported by experts [141]. Thus, the model structures of the study, as shown in Table 1 above, have surpassed this condition. Aimed at ensuring that all the study indicators meet the required criteria, the study sequel to the evaluation between the square root of the average variance extracted (AVE) and the associations between the combinations (Table 2) that determines the discriminate validity. Each relationship typically possesses a stronger causality with its own measure since all latent variables used in the study were higher than the inter-construct correlations [139].

Table 2. Fornell-Larcker criterion for discriminant validity.

\begin{tabular}{cccccc}
\hline Constructs & AVE & EO & EP & IP & IT \\
\hline EO & 0.536 & 0.710 & & & \\
EP & 0.573 & 0.639 & 0.764 & & \\
IP & 0.585 & 0.646 & 0.725 & 0.811 & 0.831 \\
IT & 0.512 & 0.716 & 0.793 & 0.712 &
\end{tabular}

Note: EO = Entrepreneurial Orientation, EP = Enterprise Performance, IP = Intellectual Property, IT = Innovation Types.

To confirm the strength of the discriminant validity, a more reliable criterion HeterotraitMonotrait Ratio (HTMT), is applied. Table 3 displays the values of the HTMT for all pairs of constructs in a format of a matrix. As illustrated in Table 3, all HTMT values are evidently less than the 0.85 threshold value. Additionally, in probing the HTMT ratios, it is imperative to know if the HTMT values are significantly distinct from 1 . The columns labeled $2.5 \%$ and $97.5 \%$ in Table 4 display the lower and upper bounds of the $95 \%$ (bias-corrected and accelerated) confidence interval. Results from Table 4 illustrate that neither of the confidence intervals include the value 1 . For instance, the lower and upper bounds of the confidence interval of HTMT for the relationship between EO and EP are 0.047 and 0.196, respectively. Hence, since the conservative HTMT threshold of 0.85 already supports discriminant validity (Table 3), the PLS algorithm results of the HTMT criterion also support the discriminant validity of the constructs. In view of this, all the model evaluation criteria have been met, giving proof for the measures of reliability and validity. 
Table 3. Heterotrait-Monotrait Ratio (HTMT).

\begin{tabular}{ccccc}
\hline Constructs & EO & EP & IP & IT \\
\hline EO & & & & \\
EP & 0.639 & & & \\
IP & 0.646 & 0.725 & 0.712 \\
IT & 0.716 & 0.793 & \\
\hline
\end{tabular}

Table 4. Direct paths bootstrap coefficients and 95\% confidence interval (CI).

\begin{tabular}{|c|c|c|c|c|c|c|c|c|}
\hline \multirow{2}{*}{$\begin{array}{c}\text { Path } \\
\text { Relations }\end{array}$} & \multirow{2}{*}{ Beta } & \multirow{2}{*}{$\begin{array}{l}\text { Standard } \\
\text { Error }\end{array}$} & \multirow{2}{*}{$t$-Value } & \multirow{2}{*}{$p$-Values } & \multicolumn{2}{|c|}{$95 \%$ CI } & \multirow{2}{*}{ R Square } & \multirow{2}{*}{ Q Square } \\
\hline & & & & & $2.5 \%$ & $97.5 \%$ & & \\
\hline $\mathrm{EO}->\mathrm{EP}$ & 0.116 & 0.040 & 2.949 & 0.003 & 0.047 & 0.196 & 0.458 & 0.251 \\
\hline IT -> EP & 0.126 & 0.053 & 2.361 & 0.019 & 0.026 & 0.233 & 0.577 & 0.318 \\
\hline IP -> EP & 0.670 & 0.058 & 11.517 & 0.000 & 0.555 & 0.779 & 0.754 & 0.415 \\
\hline $\mathrm{EO}->\mathrm{IP}$ & 0.145 & 0.045 & 3.222 & 0.008 & 0.124 & 0.167 & 0.523 & 0.311 \\
\hline $\mathrm{EO}->\mathrm{IT}$ & 0.716 & 0.041 & 17.464 & 0.000 & 0.622 & 0.786 & 0.602 & 0.466 \\
\hline IT -> IP & 0.840 & 0.029 & 27.866 & 0.000 & 0.777 & 0.893 & 0.803 & 0.567 \\
\hline
\end{tabular}

Note: $0 \leq \mathrm{Q} 2 \leq 0.15$ is small effect; $0.15<\mathrm{Q} 2 \leq 0.35$ is medium effect; $0.35<\mathrm{Q} 2$ is large effect.

\subsection{The Relationship between EO, IT and IP on EP}

This section examines the direct relationship of entrepreneurial orientation, innovation types, and intellectual property, and how they influence enterprise performance. Existing literature has acknowledged the vital roles that entrepreneurial orientation, innovation types, and intellectual property have in enterprise performance [142].

\subsubsection{Relationship between Entrepreneurial Orientation and Enterprise Performance}

The analysis as revealed in Table 4 indicate, $\mathrm{EO}(\beta=0.116, t=2.949, p=0.003)$ is statistically significant in predicting enterprise performance.

The predictive power of the endogenous construct in Table 4 demonstrates that the coefficients of the relationship and the main model outcome measure have a substantial $R^{2}$ value. The prediction of EO is substantial with an $R^{2}$ value of 0.458 . The blindfolding was utilized to assess the model's predictive relevance for each of the endogenous constructs. The running of the blindfolding procedure with an omission distance of seven, yielded cross-validated redundancy values ( $Q$ square) for EO was well above zero (0.251), providing support for the model's predictive significance. The structural model analysis reckons the significance and relevance of the structural model relationships. The bootstrapping procedure in Table 4 and Figure 2 reveals a significant relationship between EO and EP.

From the above results, an upsurge in EO will cause EP to increase by 0.116 units. This is due to the fact that amongst the items under EO, innovativeness plays a very high significant role and this is because, according to extant literature, innovativeness is a formidable force and an important factor for enterprise growth [143], especially during turbulent times. With constant innovativeness, an entrepreneur is assured of enterprise growth since the new ideas when accepted and appreciated by customers will churn out profits in return. Similarly, autonomy was also found to contribute significantly to entrepreneurial orientation as a result of the strong desire of the business owner or entrepreneur to have the independence in the development and operation of his or her ideas [144]. Risk-taking and proactiveness, even though they had a significant contribution to entrepreneurial orientation, their weights did not influence much to entrepreneurial orientation as compared to innovativeness and autonomy. This could be a result of the rational that seem to suggest that proactiveness is more active in the preliminary stages of an enterprise, and slowly declines as the enterprise grows, thus, proactiveness becomes less important once an enterprise is established. In the same vain, risk-taking is seen to be an innate part of opening an entrepreneurial venture; hence, entrepreneurial enterprises take 
additional risk and are more proactive in probing for novel business prospects in their early stages [145]. However, the lowest impact to entrepreneurial orientation was competitive aggressiveness, since according to the results it gave the lowest weight. This result is not surprising since literature has warned against too much aggressiveness especially within SMEs [146]. According to literature, too much aggression undermines an enterprise's performance, especially when small enterprises are in a price tussle with larger enterprises.

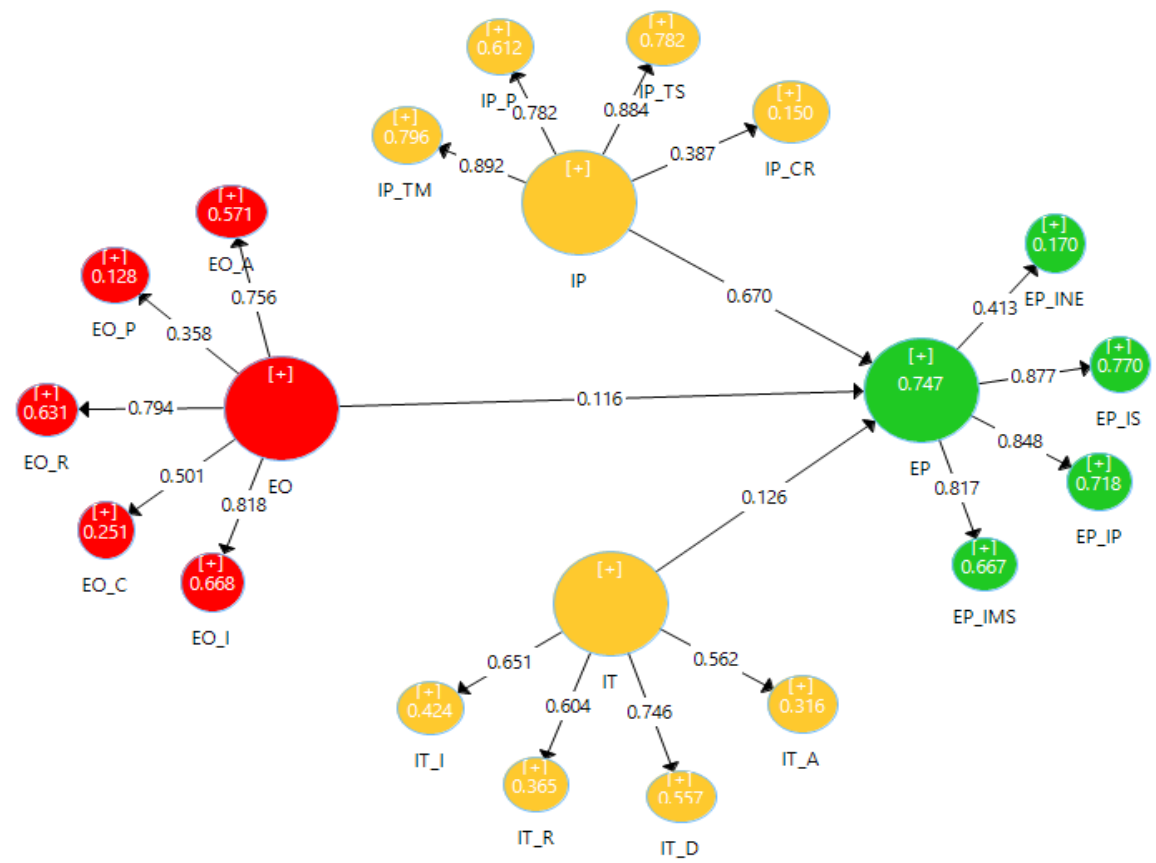

Figure 2. Structural model of the direct paths with EP as the dependent variable.

\subsubsection{Relationship between Innovation Types and Enterprise Performance}

The analysis as shown in Table 4 indicate innovation types $(\beta=0.126, t=2.361$, $p=0.019)$ is statistically significant in predicting enterprise performance.

Prediction of innovation types is considerable with an $\mathrm{R}^{2}$ value of 0.577 . Calculating the blindfolding process with the same procedure as above, the values for IT was also well above zero (0.318), providing evidence for the model's predictive significance. Figures from the bootstrapping procedure in Table 4 and Figure 2 reveal that the relationship between IT and EP is also significant.

From the above findings, an increase in innovation types will cause enterprise performance to increase by 0.126 units. The reasoning behind this is that amongst the items under innovation types, disruptive innovation contributed the most to innovation types. This is a result of the fact that once there is deployment of disruptive innovation into the market, a much faster penetration and higher degree of impact on the established markets is achieved [147]. The second most significant contributor to innovation types was incremental innovation. Incremental innovations demand a low degree of new knowledge with regard to upgrading, improving, and the modification of existing technologies, thus, most business owners or entrepreneurs are often more comfortable with incremental innovation [148]. Moreover, radical and architectural innovations also gave significant contributions to innovation types even though their influence were not up to that of disruptive and incremental innovation. This, too, could be a result of that both radical and architectural innovations concentrate more on the customer needs and perceptions so as to capture the market they exist in [149]. In general, all the items under innovation types contributed significantly to the relationship between innovation types and enterprise performance. 


\subsubsection{Relationship between Intellectual Property and Enterprise Performance}

The analysis as displayed in Table 4 specify, intellectual property $(\beta=0.670, t=11.517$, $p=0.000)$ is statistically significant in predicting enterprise performance.

Prediction of intellectual property is high with an $R^{2}$ value of 0.754 . The values for the blindfolding process for intellectual property was also well above zero (0.415), providing evidence for the model's predictive significance. Results from the bootstrapping procedure Table 4 and Figure 2 reveals that the relationship between intellectual property and enterprise performance is also significant.

From the results above, an increase in intellectual property will cause enterprise performance to increase by 0.670 units. This is as a result of the significant and high influence of trade secrets, trademarks, and copyrights have on intellectual property. Even though patent has a high impact on intellectual property is impact was not very significant compared to the other three items of intellectual property. The results are not surprising since according to literature, trade secrets is generally the most adopted strategy that the majority of SMEs use in the food processing industry, which is in line with the findings of Levine and Sichelman [150]. Trade secrets are said to be very cheap, since one does not need to pay any money to protect his or her ideas for a period of time. Secondly, the results of trademarks suggest that most business owners would like their customers to identify their products easily amongst that of their competitors. Entrepreneurs tend to brand their products in a unique way so as to differentiate themselves from imitations [151]. Copyright was the surprise package of the four items. Since copyright has to do with artistic works, it was shocking that it impacted significantly more than patents. However, most of the entrepreneurs had jingles and adverts that are played over the airwaves and television. They were of the opinion that it was necessary to copyright their jingles and short adverts since their competitors could imitate them even though they did not copyright them. Lastly, the low weights or contributions of patents as compared to the other three items of intellectual property is due to the fact that most business owners of SMEs do not see the reasons why they should pay a lot of money to protect their ideas when there are a lot of competition in the market, which confirms the research of Acosta, et al. [152].

Table 4 displays the results of the direct paths of the conceptual framework with enterprise performance as the dependent variable.

Figure 2 illustrates the pictorial view of the direct paths and how they individually influence enterprise performance significantly. The summary of hypothesis testing for the direct analysis is presented in Table 5 below.

Table 5. Summary of hypothesis testing of direct analysis.

\begin{tabular}{ccccccc}
\hline Hypothesis & Path Relations & Beta & Standard Error & $\boldsymbol{t}$-Value & $\boldsymbol{p}$-Values & Remarks \\
\hline H1 & EO -> EP & 0.116 & 0.040 & 2.949 & $0.003^{* * *}$ & Supported \\
H2 & IT -> EP & 0.126 & 0.053 & 2.361 & $0.019^{* * *}$ & Supported \\
H3 & IP -> EP & 0.670 & 0.058 & 11.517 & $0.000^{* * *}$ & Supported \\
H4 & EO -> IP & 0.145 & 0.045 & 3.222 & $0.008^{* * *}$ & Supported \\
H5 & EO -> IT & 0.716 & 0.041 & 17.464 & $0.000^{* * *}$ & Supported \\
H6 & IT -> IP & 0.840 & 0.029 & 27.866 & $0.000^{* * *}$ & Supported \\
\hline Note: ${ }^{* * *}(p<0.01$ or $1 \%)$. & & & &
\end{tabular}

\subsection{The Mediation Role of Intellectual Property and Innovation Types}

This is established to examine the casual relationship between EO, IT as endogenous variables, and EP as an endogenous variable by the insertion of a third explanatory mediator variable (IP) [153]. The bootstrapping approach in PLS-SEM is appropriate for mediation analysis, since there is no assumption about the sampling distribution of bootstrapping statistics and also applicable to small sample sizes [153]. In conducting mediation analysis in PLS-SEM, the first phase is to evaluate the direct effect of the exogenous variables (entrepreneurial orientation, innovation types, intellectual property) on 
the endogenous variable (enterprise performance), and also the direct effect amongst the exogenous variables (entrepreneurial orientation, innovation types, intellectual property), which should be significant without the mediator [154].

If the direct path is significant, the next phase is to add the mediator variable in the PLS path model and measure the significance of the indirect path. The significance of each distinct path is a needed requirement for this condition. The indirect path as shown in Table 6, can be assessed and shows a significant path relationship after running the bootstrapping procedure.

Table 6. Specific indirect effects.

\begin{tabular}{ccccccc}
\hline \multirow{2}{*}{ Path Relations } & \multirow{2}{*}{ Beta } & \multirow{2}{*}{ Standard Error } & $\boldsymbol{t}$-Value & $\boldsymbol{p}$-Values & \multicolumn{2}{c}{$\mathbf{9 5 \%}$ CI } \\
\cline { 5 - 7 } & & & & & $\mathbf{2 . 5 \%}$ & $\mathbf{9 7 . 5 \%}$ \\
\hline EO -> IP -> EP & 0.430 & 0.030 & 14.333 & 0.001 & 0.331 & 0.587 \\
EO -> IT -> EP & 0.090 & 0.039 & 2.292 & 0.024 & 0.013 & 0.163 \\
IT -> IP -> EP & 0.563 & 0.058 & 9.663 & 0.000 & 0.421 & 0.684 \\
\hline
\end{tabular}

It is established that the observed variables of each latent variable correlated adequately and satisfied the reliability and validity criteria. Against this, the model fit test was carefully noted given consideration to a range of indices tests, such as the chi-square test $=25,476.43, \mathrm{NFI}=0.962$, and SRMR $=0.058$, consistent with earlier studies [153] Table 7 presents the model fit measures of the mediation analysis.

Table 7. Model fit for mediation analysis.

\begin{tabular}{cccccc}
\hline Model & SRMR & d_ULS & d_G & $\begin{array}{c}\text { Chi- } \\
\text { Square }\end{array}$ & NFI \\
\hline Saturated Model & 0.058 & 10.889 & 22.857 & $25,476.43$ & 0.962 \\
\hline
\end{tabular}

Table 8 demonstrates clearly that innovation types (mediator) portrayed full mediating relationship with entrepreneurial orientation on enterprise performance with the variance accounted for (VAF) $85.9 \%$ of the total effect. In addition, results from Table 9 indicate that intellectual property (mediator) exhibited partial mediation with entrepreneurial orientation on enterprise performance. Results from Table 10 also suggest that intellectual property (mediator) exhibited full mediating relationship with innovation types on enterprise performance with the VAF $55.6 \%$ and $86.9 \%$ of the total effect respectively. Thus, Hypotheses, H7, H8, and H9 were all supported.

Table 8. Mediation analysis: Innovation Types as mediator.

\begin{tabular}{lccccc}
\hline $\begin{array}{c}\text { Independent } \\
\text { Variable }\end{array}$ & Direct Effect & $\begin{array}{c}\text { Indirect } \\
\text { Effect }\end{array}$ & Total Effect & VAR Range & Mediation \\
\hline $\begin{array}{c}\text { Entrepreneurial } \\
\text { Orientation }\end{array}$ & 0.116 & 0.090 & 0.105 & 0.859 & Full \\
\hline
\end{tabular}

Dependent variable: Enterprise Performance.

Table 9. Mediation analysis: Intellectual Property as mediator.

\begin{tabular}{lccccc}
\hline $\begin{array}{c}\text { Independent } \\
\text { Variable }\end{array}$ & Direct Effect & $\begin{array}{c}\text { Indirect } \\
\text { Effect }\end{array}$ & Total Effect & VAR Range & Mediation \\
\hline $\begin{array}{c}\text { Entrepreneurial } \\
\text { Orientation }\end{array}$ & 0.116 & 0.430 & 0.175 & 0.556 & Partial \\
\hline
\end{tabular}

Dependent variable: Enterprise Performance. 
Table 10. Mediation analysis: Intellectual Property as mediator.

\begin{tabular}{cccccc}
\hline $\begin{array}{c}\text { Independent } \\
\text { Variable }\end{array}$ & Direct Effect & $\begin{array}{c}\text { Indirect } \\
\text { Effect }\end{array}$ & Total Effect & VAR Range & Mediation \\
\hline $\begin{array}{c}\text { Innovation } \\
\text { Types }\end{array}$ & 0.126 & 0.563 & 0.642 & 0.869 & Full \\
\hline Dependent variable: Enterprise Performance.
\end{tabular}

Figure 3 displays the graphical view of the mediating analysis of the framework and how the mediator (intellectual property) impact the relationship between the endogenous variables and the exogenous variable.

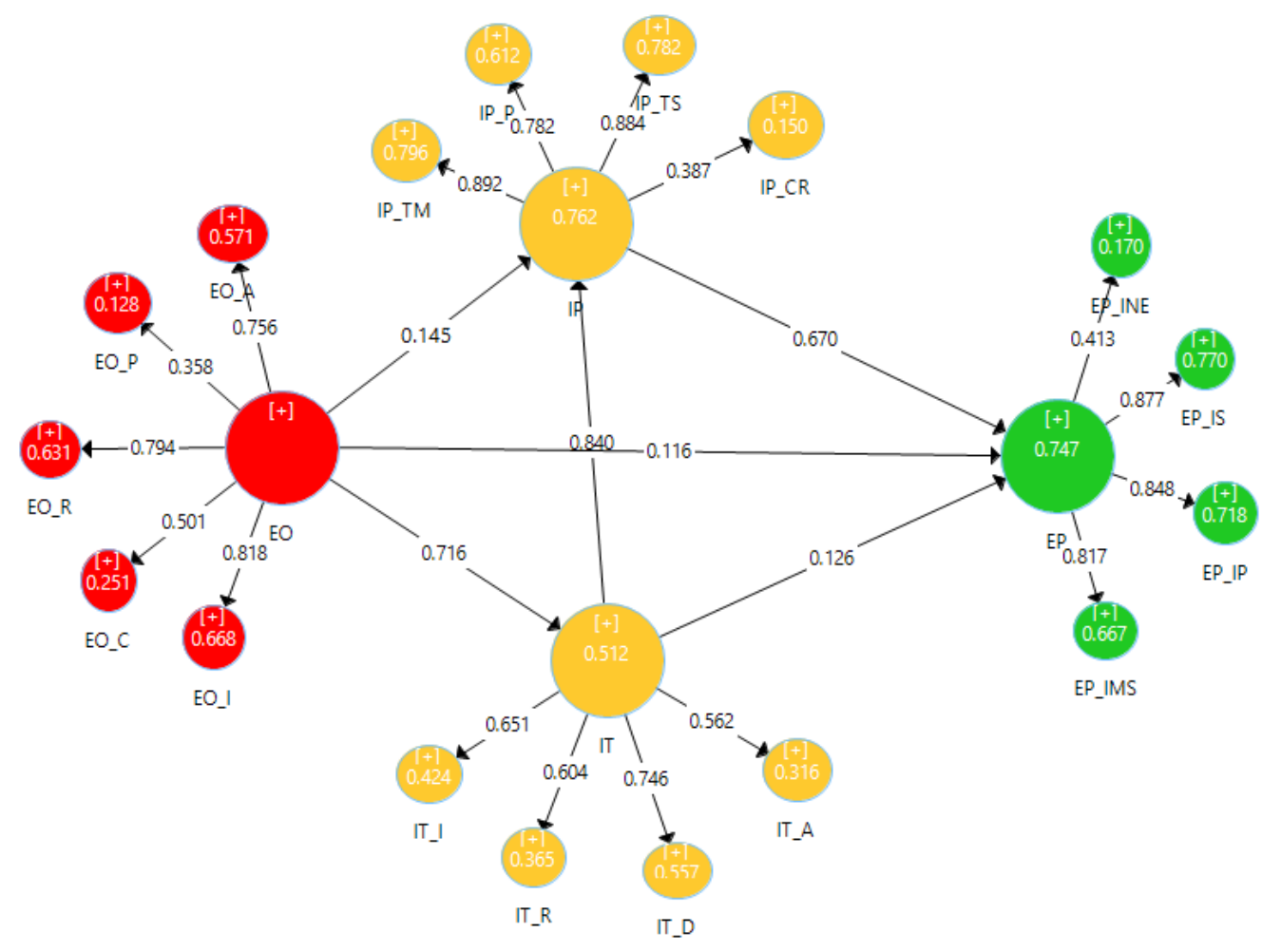

Figure 3. Structural model analysis of IT and IP as mediators.

4.5.1. The Mediation Role of Innovation Types between Entrepreneurial Orientation and Enterprise Performance

By implication, the effect of innovation types on enterprise performance fully mediated through entrepreneurial orientation demonstrating that types of innovation indicators (incremental, disruptive, radical, and architectural) contributed significantly. Among these, disruptive innovation contributed more due to consumer's latent desire in the Ghanaian food processing industry. With disruptive innovation, entrepreneurs are able to capture the market by adopting new and more convenient ways of satisfying their customers. Entrepreneurs are able to change the mindset of their customers and consumers in such a way that the consumers see previous methods as archaic. Moreover, incremental innovation played a significant role as a result of customer needs identified from current offers [155]. Most entrepreneurs adopt incremental innovation because they are able to progressively change their process, products, and service to suit their customers taste and wants. Customers' needs and taste are not static; thus, customers' taste and needs keep on changing, making owners and managers of enterprises progressively increase their innovations to suit their customers. 
4.5.2. The Mediation Role of Intellectual Property between Entrepreneurial Orientation, Innovation Types, and Enterprise Performance

From the analysis above, the influence of intellectual property on enterprise performance partially mediated through entrepreneurial orientation signifying that intellectual property indicators (trade secrets, patents, trademarks, and copyrights) were all contributing significantly. Moreover, the influence of intellectual property on enterprise performance fully mediated through innovation types suggest that the indicators of intellectual property were all contributing significantly. Among these indicators, trademarks contributed the most, and this was due to the fact that many enterprises' trademark is printed on a tag that is affixed to the good. This makes the identification of their products or services more visible and more convenient to their target market. With the influx of imitations, entrepreneurs are fully aware of the damage that an enterprise may go through if its managers are not able to differentiate and distinguish themselves uniquely from others. Secondly, trade secrets also played a vital role due to the fact that enterprises believe that an employee confidentiality agreement is the most effective way to protect their trade secrets [150]. Trade secrets are so important in the food processing industry because the recipe most entrepreneurs use are their unique secrets that makes the products different from others. Employees in these enterprises do not sometimes know the recipe unless they are highly trusted.

Table 11 below gives a summary of the hypothesis test of the mediating analysis, where all the proposed hypotheses have been significantly supported.

Table 11. Summary of hypothesis testing of the mediating analysis.

\begin{tabular}{ccccccc}
\hline Hypothesis & $\begin{array}{c}\text { Path } \\
\text { Relations }\end{array}$ & Beta & $\begin{array}{c}\text { Standard } \\
\text { Error }\end{array}$ & $\boldsymbol{t}$-Value & $\boldsymbol{p}$-Values & Remarks \\
\hline H7 & EO -> IP -> EP & 0.430 & 0.030 & 14.333 & 0.001 & Supported \\
H8 & EO -> IT -> EP & 0.090 & 0.039 & 2.292 & 0.024 & Supported \\
H9 & IT -> IP -> EP & 0.563 & 0.058 & 9.663 & 0.000 & Supported \\
\hline
\end{tabular}

\section{Conclusions}

This study extends the concept of SME growth (enterprise performance) through the examination of innovation types and intellectual property in relation between entrepreneurial orientation and enterprise performance of small and medium enterprises in the Ghanaian food processing industry during the COVID-19 pandemic. The main questions and aim of this study were to evaluate the influence of EO during a pandemic situation and the influencing effects of IT and IP in the sustainable growth of SMEs during the COVID-19 pandemic. Employing a survey sample size of 702, the study espoused structural equation modeling with the Smart-PLS version 3, alongside SPSS, to conduct the analysis, which established influence of EO on EP. The mediating effects of IT and IP were also examined.

The results of this study have shown that EO, IT, and IP positively and significantly relate to EP. Secondly, the direct relationship between the variables (EO-IT, EO-IP, and ITIP) was positive and significant. In addition, IT fully mediates the relationship between $\mathrm{EO}$ and EP, on the other hand, IP partially mediates the relationship between EO and $\mathrm{EP}$, suggesting that there are some aspects of IP that affects EP but fully mediates the relationship between IT and EP.

The analysis for the direct and mediating effect on enterprise performance show that EO strategies are significant solutions for enterprise performance of the food processing industry. The mediating effects of IT and IP strategies are also significant drivers in the relationship between EO and EP of the food processing industry of Ghana.

The results from this study will not only improve the Ghanaian food processing industry but other SMEs as a whole. The adoption of EO as a strategic management tool for enterprise performance during a pandemic situation has shown to be positive and 
significant. The use of IT and IP has also given strength to EO and how it influences enterprise performance in a pandemic situation.

Findings from this study and from literature suggests that the results do not differ from other West African countries whether Francophone or Anglophone [156,157]. This could be a result of the fact that the business settings are almost the same on the African Continent. Hence, this study suggests that the location does not influence the findings.

This study contributes to literature on what SMEs growths have in common. SMEs have been considered a vital sector in many emerging economies in prior studies. However, the sustainable SME growth in emerging economies during a pandemic period like the COVID-19 situation has not been thoroughly studied. This study, thus, addresses the research gap, by providing an in-depth understanding on the influence entrepreneurial orientation has on the sustainable growth of SMEs in emerging economies before, during, and after turbulent times.

\section{Implications}

Measures to improve the performance of SMEs are reactionary; hence, when there is an unexpected event like the COVID-19 situation, it tends to have a grave effect on businesses. Generally, entrepreneurs, business owners, managers, government agencies, government, policy think tanks, and the citizenry at large have not been proactive in putting the right strategies that will lead to the growth of SMEs especially during a lockdown period, no matter the form it takes. The enhancement and growth of Ghana's current and future economy hinges on the growth of SMEs [158]. It is, therefore, imperative that all stakeholders participate fully in realizing this dream of aiding SMEs to prosper by being proactive to curtail any unforeseen situation.

This study also discloses that $\mathrm{EO}$ is critical to an organization and has positive impacts on EP. Enterprises should, therefore, adopt EO as one of the strategies of SME business. Managers and owners should also incorporate innovation and intellectual property strategies in their day-to-day activities. Furthermore, enterprises will also have to adopt and implement the entrepreneurial orientation in all the functional areas and in their everyday activities, that is, managers and owners will not be the only entrepreneurial agents but also employees and workers of the enterprise.

Grounded on the influence of manufacturing SMEs to the Ghanaian economy, policymakers, and think tanks need to prudently reconsider their policy mix in light of the progress of this pandemic. A determined structural policy method founded on encouraging the restitution and growth of Ghanaian SMEs (in the food processing sector) through innovation, internationalization, and networking is of supreme importance to deal with the trials ahead.

Growth-oriented entrepreneurs must consider policy implications resulting from the COVID-19 pandemic and also think about novel business opportunities. This suggests a novel way of thinking that requires that there are integrated societal changes made apparent by the COVID-19 pandemic. Owing to continuing and uncertainty surrounding the future, it is significant that more research and policy emphasis on deriving new thought processes. The result will inspire a more positive and proactive approach to managing the COVID-19 pandemic that integrates entrepreneurial perspective.

\section{Limitations and Future Research}

Even though this study tries to expand our knowledge of EO and EP during a pandemic period, the results of this study have some limitations. First and foremost, this research was a cross-sectional research and it is, thus, recommended that in the future, researchers should conduct longitudinal research. Secondly, it is important to observe that this study is grounded on the small enterprises in the manufacturing sector; hence, the findings cannot be generalized on all enterprises. Further study should, therefore, consider other sectors of the economy like the agricultural sector [134]. 
Finally, this study employed the use of quantitative data. It is, therefore, our recommendation that future researchers should conduct another study using qualitative data to increase the reliability.

Author Contributions: Conceptualization, Z.L.; Data curation, O.A.A.; Formal analysis, O.A.A. and M.L.; Methodology, Z.M.; Software, Z.L.; Writing—original draft, O.A.A.; Writing—review \& editing, Z.M. and M.L. All authors have read and agreed to the published version of the manuscript.

Funding: National Natural Science Foundation of China (Grant No.71573109).

Institutional Review Board Statement: Not Applicable.

Informed Consent Statement: Not Applicable.

Conflicts of Interest: The authors declare no conflict of interest.

\section{Appendix A}

Table A1. Measurement Indicators.

\begin{tabular}{|c|c|c|c|}
\hline Construct & First Level Indicator & Second Level Indicator & Description \\
\hline \multirow[t]{21}{*}{$\begin{array}{l}\text { Entrepreneurial } \\
\text { Orientation (OE) }\end{array}$} & \multirow[t]{4}{*}{ Autonomy (EO_A) } & EO_A1 & $\begin{array}{l}\text { The manager or owner of this firm upholds strong } \\
\text { dominant authority }\end{array}$ \\
\hline & & EO_A2 & $\begin{array}{l}\text { The manager or owner of this firm has the skill and } \\
\text { will to be self-directed in the quest of opportunities }\end{array}$ \\
\hline & & EO_A3 & $\begin{array}{l}\text { Our firm grants little freedom for both individuals } \\
\text { and team work }\end{array}$ \\
\hline & & EO_A4 & $\begin{array}{l}\text { We inspire employees to make decision } \\
\text { in innovation }\end{array}$ \\
\hline & \multirow[t]{4}{*}{ Proactiveness (EO_P) } & EO_P1 & $\begin{array}{l}\text { We assist in the acknowledgement of clear } \\
\text { customer needs }\end{array}$ \\
\hline & & EO_P2 & Our firm is not overwhelmed by new circumstances \\
\hline & & EO_P3 & Our firm acts in expectation of imminent needs \\
\hline & & EO_P4 & We take the lead before competitors follow \\
\hline & \multirow[t]{4}{*}{ Risk-taking (EO_R) } & EO_R1 & \multirow{4}{*}{$\begin{array}{l}\text { Our firm recognizes risk-taking and how it func } \\
\text { We see ourselves daring } \\
\text { Our firm does not respond to } \\
\text { unconnected opportunities } \\
\text { Our firm always invests in novel technologies }\end{array}$} \\
\hline & & EO_R2 & \\
\hline & & EO_R3 & \\
\hline & & EO_R4 & \\
\hline & \multirow[t]{4}{*}{$\begin{array}{c}\text { Competitive } \\
\text { Aggressiveness (EO_C) }\end{array}$} & EO_C1 & \multirow{4}{*}{$\begin{array}{l}\text { Our firm is ready to be unconventional rather } \\
\text { rely on traditional methods of competing } \\
\text { We inspire the practice of } \\
\text { "undo-the-competitor" attitude } \\
\text { We encourage taking advantage of our } \\
\text { competitor's weakness } \\
\text { Our firm is prone to the "liability of novelty" }\end{array}$} \\
\hline & & EO_C2 & \\
\hline & & EO_C3 & \\
\hline & & EO_C4 & \\
\hline & \multirow[t]{5}{*}{$\begin{array}{c}\text { Innovativeness } \\
\text { (EO_INO) }\end{array}$} & EO_INO1 & \multirow{5}{*}{$\begin{array}{l}\text { Our firm regularly introduces new } \\
\text { services/products/processes } \\
\text { Our firm has a widely held belief that innovation is } \\
\text { an absolute necessity for the firm's future } \\
\text { Our firm is continually pursuing new opportunities } \\
\text { Our firm places a strong emphasis on new and } \\
\text { innovative products/services } \\
\text { Our leaders seek to maximize value from } \\
\text { opportunities without constraint to existing models, } \\
\text { structures or resources }\end{array}$} \\
\hline & & EO_INO2 & \\
\hline & & EO_INO3 & \\
\hline & & EO_INO4 & \\
\hline & & EO_INO5 & \\
\hline
\end{tabular}


Table A1. Cont.

\begin{tabular}{|c|c|c|c|}
\hline Construct & First Level Indicator & Second Level Indicator & Description \\
\hline \multirow[t]{18}{*}{$\begin{array}{l}\text { Innovation Types } \\
\text { (IT) }\end{array}$} & $\begin{array}{c}\text { Incremental Innovation } \\
\text { (IT_I) }\end{array}$ & IT_I1 & $\begin{array}{l}\text { Our firm regularly enhance current core } \\
\text { competencies and capabilities }\end{array}$ \\
\hline & & IT_I2 & $\begin{array}{l}\text { Our firm responds to customer needs identified } \\
\text { from current offers }\end{array}$ \\
\hline & & IT_I3 & $\begin{array}{l}\text { Our firm has a more predictable path or process, } \\
\text { particularly with respect to costs }\end{array}$ \\
\hline & & IT_I4 & $\begin{array}{l}\text { Our firm develops modest technological changes } \\
\text { from existing platforms, products, or services }\end{array}$ \\
\hline & & IT_I5 & Our firm is able to improve product/service design \\
\hline & $\begin{array}{l}\text { Radical Innovation } \\
\text { (IT_R) }\end{array}$ & IT_R1 & $\begin{array}{l}\text { Our firm works a lot with outsiders, even on a } \\
\text { temporary basis }\end{array}$ \\
\hline & & IT_R2 & $\begin{array}{l}\text { Our employees have excellent relationship with } \\
\text { people who can serve as catalysts for the } \\
\text { innovation process }\end{array}$ \\
\hline & & IT_R3 & $\begin{array}{l}\text { Our firm core performance is based on } \\
\text { new technology }\end{array}$ \\
\hline & & IT_R4 & $\begin{array}{l}\text { Our firm is able to introduce a whole new set of } \\
\text { performance features }\end{array}$ \\
\hline & $\begin{array}{l}\text { Disruptive Innovation } \\
\text { (IT_D) }\end{array}$ & IT_D1 & $\begin{array}{l}\text { Our firm starts with a purpose and a small problem } \\
\text { rather than a big idea }\end{array}$ \\
\hline & & IT_D2 & $\begin{array}{l}\text { We begin by changing a small group of people at } \\
\text { the edges }\end{array}$ \\
\hline & & IT_D3 & We tap into consumer's latent desire \\
\hline & & IT_D4 & $\begin{array}{l}\text { Our firm is based on what people do, not what they } \\
\text { say they do }\end{array}$ \\
\hline & & IT_D5 & $\begin{array}{l}\text { Our firm can be more responsive to customer's } \\
\text { behaviors and needs }\end{array}$ \\
\hline & $\begin{array}{l}\text { Architectural Innovation } \\
\text { (IT_A) }\end{array}$ & IT_A1 & $\begin{array}{l}\text { Our firm invest a lot of resources in research and } \\
\text { development (R\&D) }\end{array}$ \\
\hline & & IT_A2 & $\begin{array}{l}\text { Our firm is able to use the lessons, skills and overall } \\
\text { technology and apply them within a } \\
\text { different market. }\end{array}$ \\
\hline & & IT_A3 & Our firm continually update its technology \\
\hline & & IT_A4 & $\begin{array}{l}\text { Our firm constantly renew the organizational } \\
\text { structure to facilitate teamwork }\end{array}$ \\
\hline
\end{tabular}

Sources: $[123,125,126]$

$\begin{array}{cc}\text { Intellectual } & \text { Trade Secrets (IP_TS) } \\ \text { Property (IP) } & \text { IP_TS1 } \\ & \text { IP_TS2 } \\ & \text { IP_TS3 } \\ & \text { IP_TS4 } \\ & \text { IP_TS5 }\end{array}$

We consider trade secrets as strategic value in terms of innovative growth performance and return on investment

Our firm uses trade secret to protect knowledge that could be protected under other IP rights We acquire trade secrets from third parties Our firm apply different protection measures according to the different country where it trades in We employ payment of wage premia to discourage key employee's departures as a precaution to protect trade secrets 
Table A1. Cont.

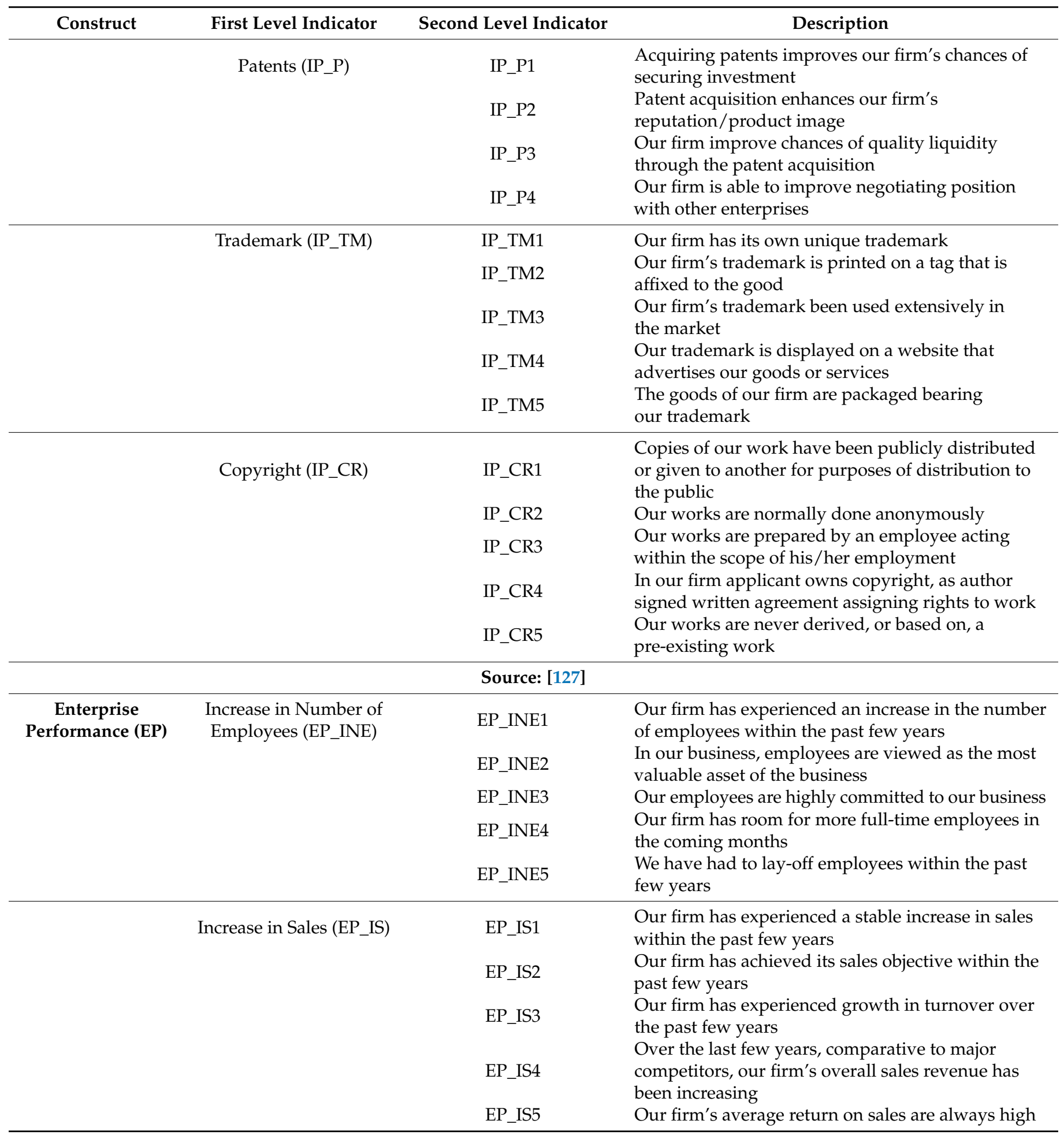


Table A1. Cont.

\begin{tabular}{|c|c|c|c|}
\hline Construct & First Level Indicator & Second Level Indicator & Description \\
\hline & \multirow[t]{4}{*}{$\begin{array}{l}\text { Increase in Profits } \\
\text { (EP_IP) }\end{array}$} & EP_IP1 & $\begin{array}{l}\text { Our firm has experienced growth in profit over the } \\
\text { past few years }\end{array}$ \\
\hline & & EP_IP2 & $\begin{array}{l}\text { Over the last few years, comparative to major } \\
\text { competitors, our firm's overall return on investment } \\
\text { has been much lower }\end{array}$ \\
\hline & & EP_IP3 & $\begin{array}{l}\text { Over the last few years, relative to major } \\
\text { competitors, our firm's overall return on assets has } \\
\text { been much higher }\end{array}$ \\
\hline & & EP_IP4 & $\begin{array}{l}\text { Despite the external business factors on our business } \\
\text { our firm has been able to make profit daily }\end{array}$ \\
\hline & \multirow[t]{4}{*}{$\begin{array}{c}\text { Increase in Market Share } \\
\text { (EP_IMS) }\end{array}$} & EP_IMS1 & $\begin{array}{l}\text { Our firm has experienced growth in market share } \\
\text { over the past few years }\end{array}$ \\
\hline & & EP_IMS2 & $\begin{array}{l}\text { Over the last few years, comparative to major } \\
\text { competitors, our firm's overall return on assets has } \\
\text { been much higher }\end{array}$ \\
\hline & & EP_IMS3 & $\begin{array}{l}\text { Our firm has a lot of customers as compared to our } \\
\text { competitors }\end{array}$ \\
\hline & & EP_IMS4 & $\begin{array}{l}\text { Our firm's pricing system is the best as compared to } \\
\text { our competitors }\end{array}$ \\
\hline
\end{tabular}

Sources: [121,122,128,129]

Table A2. Exploratory and confirmatory factor analysis.

\begin{tabular}{|c|c|c|c|c|c|c|c|c|}
\hline Constructs & $\begin{array}{c}\text { First Level } \\
\text { Construct }\end{array}$ & Items & Loadings & $\begin{array}{l}\text { Eigen } \\
\text { Value }\end{array}$ & CR & $\begin{array}{c}\text { Percentage } \\
\text { Variance }\end{array}$ & $\begin{array}{c}\text { Cronbach's } \\
\text { Alpha }\end{array}$ & AVE \\
\hline \multirow{5}{*}{$\begin{array}{l}\text { Entrepreneurial } \\
\text { Orientation (EO) }\end{array}$} & EO_INO & $\begin{array}{l}\text { EO_INO1 } \\
\text { EO_INO2 } \\
\text { EO_INO3 } \\
\text { EO_INO4 } \\
\text { EO_INO5 }\end{array}$ & $\begin{array}{l}0.731 \\
0.744 \\
0.738 \\
0.718 \\
0.787\end{array}$ & 6.849 & 0.861 & 15.720 & 0.858 & 0.554 \\
\hline & EO_A & $\begin{array}{l}\text { EO_A1 } \\
\text { EO_A } 2 \\
\text { EO_A } 3 \\
\text { EO_A } 4\end{array}$ & $\begin{array}{l}0.686 \\
0.835 \\
0.781 \\
0.692\end{array}$ & 2.025 & 0.837 & 13.405 & 0.817 & 0.564 \\
\hline & EO_R & $\begin{array}{l}\text { EO_R1 } \\
\text { EO_R2 } \\
\text { EO_R3 } \\
\text { EO_R4 }\end{array}$ & $\begin{array}{l}0.777 \\
0.738 \\
0.646 \\
0.701\end{array}$ & 1.851 & 0.808 & 13.379 & 0.767 & 0.514 \\
\hline & EO_C & $\begin{array}{l}\text { EO_C1 } \\
\text { EO_C2 } \\
\text { EO_C3 } \\
\text { EO_C4 }\end{array}$ & $\begin{array}{l}0.674 \\
0.767 \\
0.815 \\
0.697\end{array}$ & 1.420 & 0.828 & 11.404 & 0.703 & 0.548 \\
\hline & EO_P & $\begin{array}{l}\text { EO_P1 } \\
\text { EO_P2 } \\
\text { EO_P3 } \\
\text { EO_P4 }\end{array}$ & $\begin{array}{l}0.672 \\
0.723 \\
0.674 \\
0.656\end{array}$ & 1.202 & 0.776 & 9.648 & 0.712 & 0.501 \\
\hline
\end{tabular}

Note: INO (innovativeness), A (autonomy), R (Risk-taking), C (competitive aggressiveness), P (proactiveness). 
Table A3. Exploratory and confirmatory factor analysis.

\begin{tabular}{|c|c|c|c|c|c|c|c|c|}
\hline Constructs & $\begin{array}{c}\text { First Level } \\
\text { Construct }\end{array}$ & Items & Loadings & $\begin{array}{l}\text { Eigen } \\
\text { Value }\end{array}$ & CR & $\begin{array}{c}\text { Percentage } \\
\text { Variance }\end{array}$ & $\begin{array}{c}\text { Cronbach's } \\
\text { Alpha }\end{array}$ & AVE \\
\hline \multirow{4}{*}{$\begin{array}{c}\text { Innovation } \\
\text { Types (IT) }\end{array}$} & IT_I & $\begin{array}{l}\text { IT_I1 } \\
\text { IT_I2 } \\
\text { IT_I3 } \\
\text { IT_I4 } \\
\text { IT_I5 }\end{array}$ & $\begin{array}{l}0.836 \\
0.727 \\
0.785 \\
0.707 \\
0.618\end{array}$ & 7.292 & 0.856 & 17.418 & 0.839 & 0.545 \\
\hline & IT_D & $\begin{array}{l}\text { IT_D1 } \\
\text { IT_D2 } \\
\text { IT_D3 } \\
\text { IT_D4 } \\
\text { IT_D5 }\end{array}$ & $\begin{array}{l}0.812 \\
0.715 \\
0.729 \\
0.639 \\
0.602\end{array}$ & 1.454 & 0.829 & 15.251 & 0.843 & 0.501 \\
\hline & IT_A & $\begin{array}{l}\text { IT_A1 } \\
\text { IT_A2 } \\
\text { IT_A3 } \\
\text { IT_A4 }\end{array}$ & $\begin{array}{l}0.688 \\
0.685 \\
0.777 \\
0.678\end{array}$ & 1.097 & 0.800 & 13.694 & 0.749 & 0.502 \\
\hline & IT_R & $\begin{array}{l}\text { IT_R1 } \\
\text { IT_R2 } \\
\text { IT_R3 } \\
\text { IT_R4 }\end{array}$ & $\begin{array}{l}0.766 \\
0.759 \\
0.672 \\
0.622\end{array}$ & 0.936 & 0.799 & 13.520 & 0.757 & 0.500 \\
\hline
\end{tabular}

Note: I (incremental), D (disruptive), A (architectural), R (radical).

Table A4. Exploratory and confirmatory factor analysis.

\begin{tabular}{|c|c|c|c|c|c|c|c|c|}
\hline Constructs & $\begin{array}{c}\text { First Level } \\
\text { Construct }\end{array}$ & Items & Loadings & $\begin{array}{l}\text { Eigen } \\
\text { Value }\end{array}$ & CR & $\begin{array}{c}\text { Percentage } \\
\text { Variance }\end{array}$ & $\begin{array}{c}\text { Cronbach's } \\
\text { Alpha }\end{array}$ & AVE \\
\hline \multirow{4}{*}{$\begin{array}{l}\text { Intellectual } \\
\text { Property (IP) }\end{array}$} & IP_TS & $\begin{array}{l}\text { IP_TS1 } \\
\text { IP_TS2 } \\
\text { IP_TS3 } \\
\text { IP_TS4 } \\
\text { IP_TS5 }\end{array}$ & $\begin{array}{l}0.643 \\
0.722 \\
0.799 \\
0.716 \\
0.797\end{array}$ & 7.309 & 0.856 & 18.674 & 0.842 & 0.544 \\
\hline & IP_CR & $\begin{array}{l}\text { IP_CR1 } \\
\text { IP_CR2 } \\
\text { IP_CR3 } \\
\text { IP_CR4 } \\
\text { IP_CR5 }\end{array}$ & $\begin{array}{l}0.767 \\
0.838 \\
0.858 \\
0.832 \\
0.836\end{array}$ & 3.224 & 0.915 & 18.505 & 0.835 & 0.683 \\
\hline & IP_TM & $\begin{array}{l}\text { IP_TM1 } \\
\text { IP_TM2 } \\
\text { IP_TM3 } \\
\text { IP_TM4 } \\
\text { IP_TM5 }\end{array}$ & $\begin{array}{l}0.607 \\
0.639 \\
0.773 \\
0.781 \\
0.613\end{array}$ & 1.245 & 0.815 & 16.218 & 0.842 & 0.500 \\
\hline & IP_P & $\begin{array}{l}\text { IP_P1 } \\
\text { IP_P2 } \\
\text { IP_P3 } \\
\text { IP_P4 }\end{array}$ & $\begin{array}{l}0.725 \\
0.762 \\
0.814 \\
0.823\end{array}$ & 0.885 & 0.863 & 13.252 & 0.764 & 0.612 \\
\hline
\end{tabular}


Table A5. Exploratory and confirmatory factor analysis.

\begin{tabular}{|c|c|c|c|c|c|c|c|c|}
\hline Constructs & $\begin{array}{l}\text { First Level } \\
\text { Construct }\end{array}$ & Items & Loadings & $\begin{array}{l}\text { Eigen } \\
\text { Value }\end{array}$ & CR & $\begin{array}{c}\text { Percentage } \\
\text { Variance }\end{array}$ & $\begin{array}{c}\text { Cronbach's } \\
\text { Alpha }\end{array}$ & AVE \\
\hline \multirow{4}{*}{$\begin{array}{c}\text { Enterprise } \\
\text { Performance (EP) }\end{array}$} & EP_INE & $\begin{array}{l}\text { EP_INE1 } \\
\text { EP_INE2 } \\
\text { EP_INE3 } \\
\text { EP_INE4 } \\
\text { EP_INE5 }\end{array}$ & $\begin{array}{l}0.863 \\
0.862 \\
0.809 \\
0.830 \\
0.820\end{array}$ & 6.367 & 0.921 & 19.915 & 0.866 & 0.701 \\
\hline & EP_IS & $\begin{array}{l}\text { EP_IS1 } \\
\text { EP_IS2 } \\
\text { EP_IS3 } \\
\text { EP_IS4 } \\
\text { EP_IS5 }\end{array}$ & $\begin{array}{l}0.694 \\
0.673 \\
0.767 \\
0.790 \\
0.681\end{array}$ & 3.244 & 0.844 & 17.774 & 0.845 & 0.522 \\
\hline & EP_IMS & $\begin{array}{l}\text { EP_IMS1 } \\
\text { EP_IMS2 } \\
\text { EP_IMS3 } \\
\text { EP_IMS4 }\end{array}$ & $\begin{array}{l}0.731 \\
0.721 \\
0.719 \\
0.603\end{array}$ & 1.224 & 0.788 & 14.491 & 0.752 & 0.500 \\
\hline & EP_IP & $\begin{array}{l}\text { EP_IP1 } \\
\text { EP_IP2 } \\
\text { EP_IP3 } \\
\text { EP_IP4 }\end{array}$ & $\begin{array}{l}0.672 \\
0.772 \\
0.770 \\
0.791\end{array}$ & 1.061 & 0.839 & 13.912 & 0.767 & 0.567 \\
\hline
\end{tabular}

Note: INE (increase in number of employees), IS (increase in sales), IMS (increase in market share), IP (increase in profits).

\section{References}

1. WHO. Available online: http://www.who.int (accessed on 8 December 2020).

2. Chen, H.; Guo, J.; Wang, C.; Luo, F.; Yu, X.; Zhang, W.; Li, J.; Zhao, D.; Xu, D.; Gong, Q. Clinical characteristics and intrauterine vertical transmission potential of COVID-19 infection in nine pregnant women: A retrospective review of medical records. Lancet 2020, 395, 809-815. [CrossRef]

3. Donthu, N.; Gustafsson, A. Effects of COVID-19 on business and research. J. Bus. Res. 2020, 117, 284. [CrossRef] [PubMed]

4. Abor, J.; Quartey, P. Issues in SME development in Ghana and South Africa. Int. Res. J. Financ. Econ. 2010, 39, $215-228$.

5. Obi, J.; Ibidunni, A.S.; Tolulope, A.; Olokundun, M.A.; Amaihian, A.B.; Borishade, T.T.; Fred, P. Contribution of small and medium enterprises to economic development: Evidence from a transiting economy. Data Brief. 2018, 18, 835-839. [CrossRef] [PubMed]

6. OECD. Report of the Chair of the Working Group on the Future Size and Membership of the Organisation to Council; OECD: Paris, France, 2017.

7. Tehseen, S.; Ahmed, F.U.; Qureshi, Z.H.; Uddin, M.J.; Ramayah, T. Entrepreneurial competencies and SMEs' growth: The mediating role of network competence. Asia-Pac. J. Bus. Adm. 2019, 11, 1. [CrossRef]

8. Agbola, R.M.; Amoah, A. Coding Systems and Effective Inventory Management of SMEs in the Ghanaian Retail Industry. Cent. Inq. 2019, 1, 46-65.

9. Stephen, E. SMEs contribute 70\% to Ghana's GDP. Today Newspaper, 17 November 2017.

10. Affum, E.K.; Wang, H. The Food Industry in Ghana: Demystifying the Innovation and Quality Conundrum. Food Ind. 2019, 10. [CrossRef]

11. The Institute of Statistical, Social and Economic Research (ISSER). Social and Economic Research. In The State of the Ghanaian Economy in 2016; University of Ghana: Legon Boundary, Accra, Ghana, 2017.

12. UNESCO. Manufacturing: Struggling to survive. In UNESCO Ghana Report; Ghana Education Service: Accra, Ghana, 2010.

13. Sutton, J.; Kpentey, B. An Enterprise Map of Ghana; International Growth Centre in Association with the London Publishing Partnership: London, UK, 2012; Volume 2.

14. GNCCI Business Survey. COVID-19 Examining the Concerns and Expectations of Businesses in Ghana Finalised; Ghana National Chamber of Commerce and Industry: Tarkwa, Ghana, 2020; pp. 1-27.

15. Yawised, K.; O'Donohue, W. Social Customer Relationship Management in Small and Medium Enterprises: Overcoming Barriers to Success. In Management Science; Springer: Cham, Switzerland, 2019; pp. 157-181.

16. Petković, S.; Jäger, C.; Sašić, B. Challenges of small and medium sized companies at early stage of development: Insights from Bosnia and Herzegovina. Manag. J. Contemp. Manag. Issues 2016, 21, 45-76.

17. Poudel, K.P.; Carter, R.; Lonial, S. The Impact of Entrepreneurial Orientation, Technological Capability, and Consumer Attitude on Firm Performance: A Multi-Theory Perspective. J. Small Bus. Manag. 2019, 2, 268-295. [CrossRef]

18. Amponsah, R.; Frimpong, I.A. Ghana in the Face of COVID-19: Economic Impact of Coronavirus (2019-NCOV) Outbreak on Ghana. Open J. Bus. Manag. 2020, 8, 1404. [CrossRef] 
19. Quaye, D.; Mensah, I. Marketing innovation and sustainable competitive advantage of manufacturing SMEs in Ghana. Manag. Decis. 2019, 57, 7. [CrossRef]

20. Quartey, P.; Turkson, E.; Abor, J.Y.; Iddrisu, A.M. Financing the growth of SMEs in Africa: What are the contraints to SME financing within ECOWAS? Rev. Dev. Financ. 2017, 7, 18-28. [CrossRef]

21. Zeebaree, M.R.Y.; Siron, R.B. The impact of entrepreneurial orientation on competitive advantage moderated by financing support in SMEs. Int. Rev. Manag. Mark. 2017, 7, 43-52.

22. Sirivanh, T.; Sukkabot, S.; Sateeraroj, M. The effect of entrepreneurial orientation and competitive advantage on SMEs' growth: A structural equation modeling study. Int. J. Bus. Soc. Sci. 2014, 5, 6.

23. Sabahi, S.; Parast, M.M. The impact of entrepreneurship orientation on project performance: A machine learning approach. Int. J. Prod. Econ. 2020, 226, 107621. [CrossRef]

24. Devece, C.; Peris-Ortiz, M.; Rueda-Armengot, C. Entrepreneurship during economic crisis: Success factors and paths to failure. J. Bus. Res. 2016, 69, 5366-5370. [CrossRef]

25. Desbureaux, S.; Kaota, A.; Lunanga, E.; Stoop, N.; Verpoorten, M. Covid-19 vs. Ebola: Impact on households and SMEs in Nord Kivu, DR Congo; IOB Working Paper: Antwerp, Belgium, 2020; pp. 1-25.

26. Kottika, E.; Özsomer, A.; Rydén, P.; Theodorakis, I.G.; Kaminakis, K.; Kottikas, K.G.; Stathakopoulos, V. We survived this! What managers could learn from SMEs who successfully navigated the Greek economic crisis. Ind. Mark. Manag. 2020, 88, 352-365. [CrossRef]

27. Kraus, S.; Rigtering, J.C.; Hughes, M.; Hosman, V. Entrepreneurial orientation and the business performance of SMEs: A quantitative study from the Netherlands. Rev. Manag. Sci. 2012, 6, 161-182. [CrossRef]

28. Asad, M.; Shabbir, M.; Salman, R.; Haider, S.; Ahmad, I. Do entrepreneurial orientation and size of enterprise influence the performance of micro and small enterprises? A study on mediating role of innovation. Manag. Sci. Lett. 2018, 8, 1015-1026. [CrossRef]

29. Kee, D.M.H.; Rahman, N.A. Analyzing entrepreneurial orientation impact on start-up success with support service as moderator: A PLS-SEM approach. Bus. Econ. Horiz. (BEH) 2017, 13, 128-141. [CrossRef]

30. Van Gelderen, M.; Kibler, E.; Kautonen, T.; Munoz, P.; Wincent, J. Mindfulness and taking action to start a new business. J. Small Bus. Manag. 2019, 57, 489-506. [CrossRef]

31. Moreno, A.M.; Casillas, J.C. Entrepreneurial orientation and growth of SMEs: A causal model. Entrep. Theory Pract. 2008, 32, 507-528. [CrossRef]

32. Rezaei, J.; Ortt, R. Entrepreneurial orientation and firm performance: The mediating role of functional performances. Manag. Res. Rev. 2018, 41, 878-900. [CrossRef]

33. Juergensen, J.; Guimón, J.; Narula, R. European SMEs amidst the COVID-19 crisis: Assessing impact and policy responses. J. Ind. Bus. Econ. 2020, 47, 499-510. [CrossRef]

34. Nuscheler, D.; Engelen, A.; Zahra, S.A. The role of top management teams in transforming technology-based new ventures' product introductions into growth. J. Bus. Ventur. 2019, 34, 122-140. [CrossRef]

35. Covin, J.G.; Lumpkin, G.T. Entrepreneurial orientation theory and research: Reflections on a needed construct. Entrep. Theory Pract. 2011, 35, 855-872. [CrossRef]

36. Lumpkin, G.T.; Dess, G.G. Clarifying the entrepreneurial orientation construct and linking it to performance. Acad. Manag. Rev. 1996, 21, 135-172. [CrossRef]

37. Lampe, J.; Kraft, P.S.; Bausch, A. Mapping the Field of Research on Entrepreneurial Organizations (1937-2016): A Bibliometric Analysis and Research Agenda. Entrep. Theory Pract. 2019, 44, 784-816. [CrossRef]

38. Kuratko, D.F.; Morris, M.H. Examining the future trajectory of entrepreneurship. J. Small Bus. Manag. 2018, 56, 11-23. [CrossRef]

39. Mintzberg, H. Strategy-making in three modes. Calif. Manag. Rev. 1973, 16, 44-53. [CrossRef]

40. Covin, J.G.; Slevin, D.P. Strategic management of small firms in hostile and benign environments. Strateg. Manag. J. 1989, 10, 75-87. [CrossRef]

41. Miller, D. The correlates of entrepreneurship in three types of firms. Manag. Sci. 1983, 29, 770-791. [CrossRef]

42. Covin, J.G.; Slevin, D.P. A conceptual model of entrepreneurship as firm behavior. Entrep. Theory Pract. 1991, 16, 7-26. [CrossRef]

43. Kuratko, D.F. Entrepreneurial leadership in the 21st century: Guest editor's perspective. J. Leadersh. Organ. Stud. 2007, 13, 1-11. [CrossRef]

44. Zhang, Y.; Zhang, X.E. The effect of entrepreneurial orientation on business performance: A role of network capabilities in China. J. Chin. Entrep. 2012, 4, 132-142. [CrossRef]

45. Aziz, K.; Hasnain, S.S.U.; Awais, M.; Shahzadi, I.; Afzal, M.M. The Impact of Entrepreneurial Orientation on SME Performance in Pakistan: A Qualitative Analysis. Int. J. Eng. Inf. Syst. (IJEAIS) 2017, 1, 107-112.

46. Pratono, A.H.; Mahmood, R. Entrepreneurial orientation and firm performance: How can micro, small and medium-sized enterprises survive environmental turbulence? Pac. Sci. Rev. B Humanit. Soc. Sci. 2015, 1, 85-91. [CrossRef]

47. Taheri, B.; Bititci, U.; Gannon, M.J.; Cordina, R. Investigating the influence of performance measurement on learning, entrepreneurial orientation and performance in turbulent markets. Int. J. Contemp. Hosp. Manag. 2019, 31, 1224-1246. [CrossRef]

48. Simba, A.; Thai, M.T.T. Advancing Entrepreneurial Leadership as a Practice in MSME Management and Development. J. Small Bus. Manag. 2019, 57, 397-416. [CrossRef] 
49. Sahoo, S.; Yadav, S. Entrepreneurial orientation of SMEs, total quality management and firm performance. J. Manuf. Technol. Manag. 2017, 28, 892-912. [CrossRef]

50. Rauch, A.; Wiklund, J.; Lumpkin, G.; Frese, M. Entrepreneurial Orientation and Business Performance: Cumulative Empirical Evidence; University of Exeter: Exeter, England, 2009. [CrossRef]

51. Vrontis, D.; Thrassou, A.; Chebbi, H.; Yahiaoui, D. Transcending innovativeness towards strategic reflexivity. Qual. Mark. Res. Int. J. 2012, 15, 420-437. [CrossRef]

52. Abdilahi, M.H.; Hassan, A.A.; Muhumed, M.M. The Impact of Innovation on Small and Medium Enterprises Performance: Empirical Evidence from Hargeisa, Somaliland. Int. J. Acad. Res. Bus. Soc. Sci. 2017, 7, 14-28. [CrossRef]

53. Olughor, R.J. Effect of innovation on the performance of SMEs organizations in Nigeria. Management 2015, 5, 90-95.

54. Rosli, M.M.; Sidek, S. The Impact of Innovation on the Performance of Small and Medium Manufacturing Enterprises: Evidence from Malaysia. J. Innov. Manag. Small Medium Enterp. 2013, 2013, 1. [CrossRef]

55. Welsch, H.; Price, D.P.; Stoica, M. Innovation, Performance and Growth Intentions in SMEs. Int. J. Econ. Manag. Eng. 2013, 3, 176.

56. Zwingina, C.; Opusunju, M. Impact of innovation on the performance of small and medium scale enterprise in Gwagwalada, Abuja. Int. J. Entrep. Dev. Educ. Sci. Res. 2017, 4, 31-43.

57. Li, B.; Huang, L. The Effect of Incremental Innovation and Disruptive Innovation on the Sustainable Development of Manufacturing in China. Sage Open 2019, 9, 2158244019832700. [CrossRef]

58. Zentner, A. Disruptive Innovation: A Catalyst for Change in Business and Market Modeling. 2015. Available online: https: / / ssrn.com/abstract=2522812 (accessed on 8 December 2020).

59. Shih, T.-Y. Determinants of enterprises radical innovation and performance: Insights into strategic orientation of cultural and creative enterprises. Sustainability 2018, 10, 1871. [CrossRef]

60. Li, H.; Atuahene-Gima, K. Product innovation strategy and the performance of new technology ventures in China. Acad. Manag. J. 2001, 44, 1123-1134.

61. Rajapathirana, R.J.; Hui, Y. Relationship between innovation capability, innovation type, and firm performance. J. Innov. Knowl. 2018, 3, 44-55. [CrossRef]

62. Porter, M.E.; Kramer, M.R. Creating shared value. In Managing Sustainable Business; Springer: Dordrecht, The Netherlands, 2019; pp. 323-346.

63. Kretschmer, M.; Soetendorp, R. The strategic use of business method patents: A pilot study of out of court settlements. J. E-Bus. 2001, 2, 9-38.

64. Chirico, F.; Criaco, G.; Baù, M.; Naldi, L.; Gomez-Mejia, L.R.; Kotlar, J. To patent or not to patent: That is the question. Intellectual property protection in family firms. Entrep. Theory Pract. 2018, 44, 339-367. [CrossRef]

65. Artz, K.W.; Norman, P.M.; Hatfield, D.E.; Cardinal, L.B. A longitudinal study of the impact of R\&D, patents, and product innovation on firm performance. J. Prod. Innov. Manag. 2010, 27, 725-740.

66. Holgersson, M.; Granstrand, O. Patenting motives, technology strategies, and open innovation. Manag. Decis. 2017, 55, 1265-1284 [CrossRef]

67. Chang, K.-C.; Chen, D.-Z.; Huang, M.-H. The relationships between the patent performance and corporation performance. J. Informetr. 2012, 6, 131-139. [CrossRef]

68. Ernst, H. Patent applications and subsequent changes of performance: Evidence from time-series cross-section analyses on the firm level. Res. Policy 2001, 30, 143-157. [CrossRef]

69. Guo-Fitoussi, L.; Bounfour, A.; Rekik, S. Intellectual property rights, complementarity and the firm's economic performance. Int. J. Intellect. Prop. Manag. 2019, 9, 136-165.

70. Rank, O.N.; Strenge, M. Entrepreneurial orientation as a driver of brokerage in external networks: Exploring the effects of risk taking, proactivity, and innovativeness. Strateg. Entrep. J. 2018, 12, 482-503. [CrossRef]

71. Jeong, S.; McLean, G.N.; Park, S. Understanding informal learning in small-and medium-sized enterprises in South Korea. J. Workplace Learn. 2018, 30, 89-107. [CrossRef]

72. Athreye, S.; Fassio, C. Why do innovators not apply for trademarks? The role of information asymmetries and collaborative innovation. Ind. Innov. 2020, 27, 134-154. [CrossRef]

73. Shane, S.; Venkataraman, S. The promise of entrepreneurship as a field of research. Acad. Manag. Rev. 2000, 25, 217-226. [CrossRef]

74. Kraus, S.; Burtscher, J.; Vallaster, C.; Angerer, M. Sustainable entrepreneurship orientation: A reflection on status-quo research on factors facilitating responsible managerial practices. Sustainability 2018, 10, 444. [CrossRef]

75. Carvalho, N.; Yordanova, Z. Why say no to innovation? Evidence from industrial SMEs in European Union. J. Technol. Manag. Innov. 2018, 13, 43-56. [CrossRef]

76. Minafam, Z. Corporate Entrepreneurship and Innovation Performance in Established Iranian Media Firms. Ad-Minister 2019, 34, 77-100.

77. Anderson, B.S.; Covin, J.G.; Slevin, D.P. Understanding the relationship between entrepreneurial orientation and strategic learning capability: An empirical investigation. Strateg. Entrep. J. 2009, 3, 218-240. [CrossRef]

78. Wang, X.; Dass, M.; Arnett, D.B.; Yu, X. Understanding firms' relative strategic emphases: An entrepreneurial orientation explanation. Ind. Mark. Manag. 2019, 84, 151-164. [CrossRef] 
79. Wales, W.J. Entrepreneurial orientation: A review and synthesis of promising research directions. Int. Small Bus. J. $2016,34,3-15$. [CrossRef]

80. Hafeez, M.H.; Shariff, M.N.M.; Lazim, H.B.M. Relationship between entrepreneurial orientation, firm resources, SME branding and firm's performance: Is innovation the missing link. Am. J. Ind. Bus. Manag. 2012, 2, 153-159. [CrossRef]

81. Harms, R.; Schulz, A.; Kraus, S.; Fink, M. The conceptualisation of'opportunity'in strategic management research. Int. J. Entrep. Ventur. 2009, 1, 57-71. [CrossRef]

82. Arzubiaga, U.; Kotlar, J.; De Massis, A.; Maseda, A.; Iturralde, T. Entrepreneurial orientation and innovation in family SMEs: Unveiling the (actual) impact of the Board of Directors. J. Bus. Ventur. 2018, 33, 455-469. [CrossRef]

83. Omar, N.A.; Aris, H.M.; Nazri, M.A. The effect of entrepreneurial orientation, innovation capability and knowledge creation on firm performance: A perspective on small scale entrepreneurs. J. Pengur. (J. Manag.) 2016, 48. [CrossRef]

84. Naidu, A.A. Examining the Relationship between Entrepreneurial Orientation, the Strategic Decision-Making Process and Organisational Performance: A Study of Singapore SMEs. Ph.D. Thesis, The University of Western Australia, Crawley, WA, Australia, 2016.

85. Madhoushi, M.; Sadati, A.; Delavari, H.; Mehdivand, M.; Mihandost, R. Entrepreneurial orientation and innovation performance: The mediating role of knowledge management. Asian J. Bus. Manag. 2011, 3, 310-316.

86. Nasir, W.M. The Relationship between Strategic Orientation and Firm Performance: Evidence from Small and Medium Enterprises in Malaysia; Victoria University: Footscray, VIC, Australia, 2013.

87. Bodlaj, M.; Čater, B. The Impact of Environmental Turbulence on the Perceived Importance of Innovation and Innovativeness in SMEs. J. Small Bus. Manag. 2019, 2, 417-435. [CrossRef]

88. Zhai, Y.-M.; Sun, W.-Q.; Tsai, S.-B.; Wang, Z.; Zhao, Y.; Chen, Q. An Empirical Study on Entrepreneurial Orientation, Absorptive Capacity, and SMEs' Innovation Performance: A Sustainable Perspective. Sustainability 2018, 10, 314. [CrossRef]

89. Tidd, J.; Bessant, J.R. Managing Innovation: Integrating Technological, Market and Organizational Change; John Wiley \& Sons: Hoboken, NJ, USA, 2018.

90. Fink, C.; Raffo, J. What Role for Intellectual Property in Industrial Development? In Intellectual Property and Development: Understanding the Interfaces; Springer: Singapore, 2019; pp. 119-136.

91. Chandra, G.R.; Liaqat, I.A. Commercialization of Intellectual Property; an Insight for Technocrats. In Proceedings of the 2019 International Conference on Automation, Computational and Technology Management (ICACTM), London, UK, 24-26 April 2019; pp. 373-378.

92. Morikawa, M. Innovation in the service sector and the role of patents and trade secrets: Evidence from Japanese firms. J. Jpn. Int. Econ. 2019, 51, 43-51. [CrossRef]

93. Kalanje, C.M. Role of Intellectual Property in Innovation and New Product Development; World Intellectual Property Organization: Geneva, Switzerland, 2006.

94. Naveiro, R. Role of Intellectual Property in Innovation and New Product Development. Master's Thesis, Federal University of Rio de Janeiro, Rio de Janeiro, Brazil, 2013.

95. Iksanova, L.; Kashapov, N. Intellectual property as a factor of increasing innovation activity of economic entities. IOP Conf. Ser. Mater. Sci. Eng. 2018, 412, 012028. [CrossRef]

96. Sherwood, R.M. Intellectual Property and Economic Development; Routledge: New York, NY, USA, 2019.

97. Rushing, F.W. Intellectual Property Rights in Science, Technology, and Economic Performance: International Comparisons; Routledge: New York, NY, USA, 2019.

98. Dzenopoljac, V.; Yaacoub, C.; Elkanj, N.; Bontis, N. Impact of intellectual capital on corporate performance: Evidence from the Arab region. J. Intellect. Cap. 2017, 18, 884-903. [CrossRef]

99. Kamm, J.B.; Shuman, J.C.; Seeger, J.A.; Nurick, A.J. Entrepreneurial teams in new venture creation: A research agenda. Entrep. Theory Pract. 1990, 14, 7-17. [CrossRef]

100. Shan, P.; Song, M.; Ju, X. Entrepreneurial orientation and performance: Is innovation speed a missing link? J. Bus. Res. 2016, 69, 683-690. [CrossRef]

101. Stuart, R.; Abetti, P.A. Start-up ventures: Towards the prediction of initial success. J. Bus. Ventur. 1987, 2, 215-230. [CrossRef]

102. Cheah, J.; Amran, A.; Yahya, S. External oriented resources and social enterprises' performance: The dominant mediating role of formal business planning. J. Clean. Prod. 2019, 236, 117693. [CrossRef]

103. Calisir, F.; Altin, G.C.; Guzelsoy, E. Impacts of learning orientation on product innovation performance. Learn. Organ. 2013, 20. [CrossRef]

104. Avlonitis, G.J.; Salavou, H.E. Entrepreneurial orientation of SMEs, product innovativeness, and performance. J. Bus. Res. 2007, 60, 566-575. [CrossRef]

105. Hami, N.; Muhamad, M.R.; Ebrahim, Z. The impact of sustainable manufacturing practices and innovation performance on economic sustainability. Procedia Cirp 2015, 26, 190-195. [CrossRef]

106. Tajasom, A.; Hung, D.K.M.; Nikbin, D.; Hyun, S.S. The role of transformational leadership in innovation performance of Malaysian SMEs. Asian J. Technol. Innov. 2015, 23, 172-188. [CrossRef]

107. Lee, C.; Hallak, R.; Sardeshmukh, S.R. Innovation, entrepreneurship, and restaurant performance: A higher-order structural model. Tour. Manag. 2016, 53, 215-228. [CrossRef] 
108. Davila, T.; Epstein, M.; Shelton, R. Making Innovation Work: How to Manage It, Measure It, and Profit from It; FT Press: Upper Saddle River, NJ, USA, 2012.

109. Joe, T.; Fiona, S. Innovation Heroes: Understanding Customers as a Valuable Innovation Resource; World Scientific: Singapore, 2018; Volume 31.

110. Kronthaler, M.M. Innovation Heroes-Understanding Customers as a Valuable Innovation Resource; Fiona, S., Joe, T., Eds.; World Scientific Publishing Europe: London, UK, 2018; ISBN 978-1786345363.

111. de Zubielqui, G.C.; Lindsay, N.; Lindsay, W.; Jones, J. Knowledge quality, innovation and firm performance: A study of knowledge transfer in SMEs. Small Bus. Econ. 2019, 53, 145-164. [CrossRef]

112. Zhu, Q.; Zou, F.; Zhang, P. The role of innovation for performance improvement through corporate social responsibility practices among small and medium-sized suppliers in C hina. Corp. Soc. Responsib. Environ. Manag. 2019, 26, 341-350. [CrossRef]

113. Ramadani, V.; Hisrich, R.D.; Abazi-Alili, H.; Dana, L.-P.; Panthi, L.; Abazi-Bexheti, L. Product innovation and firm performance in transition economies: A multi-stage estimation approach. Technol. Forecast. Soc. Chang. 2019, 140, 271-280. [CrossRef]

114. Dabić, M.; Lažnjak, J.; Smallbone, D.; Švarc, J. Intellectual capital, organisational climate, innovation culture, and SME performance: Evidence from Croatia. J. Small Bus. Enterp. Dev. 2019, 26, 4. [CrossRef]

115. Khalique, M.; Bontis, N.; Shaari, J.A.N.B.; Yaacob, M.R.; Ngah, R. Intellectual capital and organisational performance in Malaysian knowledge-intensive SMEs. Int. J. Learn. Intellect. Cap. 2018, 15, 20-36. [CrossRef]

116. Deng, P.; Lu, H.; Hong, J.; Chen, Q.; Yang, Y. Government R\&D subsidies, intellectual property rights protection and innovation. Chin. Manag. Stud. 2019, 13, 363-378.

117. Davoudi, S.M.M.; Fartash, K.; Venera, G.Z.; Asiya, M.B.; Rashad, A.K.; Anna, V.B.; Zhanna, M.S. Testing the Mediating Role of Open Innovation on the Relationship between Intellectual Property Rights and Organizational Performance: A Case of Science and Technology Park. Eurasia J. Math. Sci. Technol. Educ. 2018, 14, 1359-1369. [CrossRef]

118. Ibarra Cisneros, M.A.; Hernandez-Perlines, F. Intellectual capital and Organization performance in the manufacturing sector of Mexico. Manag. Decis. 2018, 56, 1818-1834. [CrossRef]

119. Aminu, M.I.; Mahmood, R. Mediating role of dynamic capabilities on the relationship between intellectual capital and performance: A hierarchical component model perspective in PLS-SEM path modeling. Res. J. Bus. Manag. 2015, 9, 443-456. [CrossRef]

120. Alembummah, A.B. Entrepreneurial Orientation and SME Growth: A Study of the Food Processing Sector of Ghana; MPhil, University of Ghana: Legon Boundary, Accra, Ghana, 2015.

121. Venter, A. An Analysis of the Influence of Entrepreneurial Orientation on Business Success in Selected Small and Medium-Sized Enterprises; North-West University: Evanston, IL, USA, 2014.

122. Damanpour, F. Organizational innovation: A meta-analysis of effects of determinants and moderators. Acad. Manag. J. 1991, 34, 555-590.

123. Moch, M.; Pondy, L. The structure of chaos: Organized anarchy as a response to ambiguity. JSTOR 1977, 22, 351-362. [CrossRef]

124. Dewar, R.D.; Dutton, J.E. The adoption of radical and incremental innovations: An empirical analysis. Manag. Sci. 1986, 32, 1422-1433. [CrossRef]

125. Collins, P.D.; Hage, J.; Hull, F.M. Organizational and technological predictors of change in automaticity. Acad. Manag. J. 1988, 31, 512-543.

126. Linton, G. The Future, Entrepreneurship, and Innovation: A Note on the Importance of the Getting Entrepreneurship and Innovation Right for a Sustainable Future; Örebro University School of Business: Örebro, Sweden, 2018.

127. Wu, D. Measuring Performance in Small and Medium Enterprises in the Information and Communication Technology Industries. Ph.D. Thesis, RMIT University, Melbourne, VIC, Australia, February 2009.

128. Akrofi, A.E. The Impact of External Business Environment Factors on Performance of Small E Medium Sized Enterprises in the Pharmaceutical Industry in Kumasi Metropolis; Kwame Nkrumah University of Science and Technology: Kumasi, Ghana, 2017.

129. Kuppelwieser, V.G.; Putinas, A.-C.; Bastounis, M. Toward application and testing of measurement scales and an example. Sociol. Methods Res. 2019, 48, 326-349. [CrossRef]

130. Li, W.; Sadick, M.A.; Musah, A.-A.I.; Mustapha, S. The Moderating Effect of Social Innovation in Perspectives of Shared Value Creation in the Educational Sector of Ghana. Sustainability 2018, 10, 4216. [CrossRef]

131. Ringle, C.M.; Wende, S.; Becker, J.-M. SmartPLS 3. SmartPLS GmbH, Boenningstedt. J. Serv. Sci. Manag. $2015,10$.

132. Hair, J.F.; Ringle, C.M.; Sarstedt, M. PLS-SEM: Indeed a silver bullet. J. Mark. Theory Pract. 2011, 19, 139-152. [CrossRef]

133. Sarstedt, M.; Ringle, C.M.; Smith, D.; Reams, R.; Hair, J.F., Jr. Partial least squares structural equation modeling (PLS-SEM): A useful tool for family business researchers. J. Fam. Bus. Strategy 2014, 5, 105-115. [CrossRef]

134. Khan, H.; Zhiqiang, M.; Abubakari Sadick, M.; Ibn Musah, A.-A. Investigating the Role of Psychological Contract Breach, Political Skill and Work Ethic on Perceived Politics and Job Attitudes Relationships: A Case of Higher Education in Pakistan. Sustainability 2018, 10, 4737. [CrossRef]

135. Cegarra-Navarro, J.-G.; Reverte, C.; Gómez-Melero, E.; Wensley, A.K. Linking social and economic responsibilities with financial performance: The role of innovation. Eur. Manag. J. 2016, 34, 530-539. [CrossRef]

136. Yeung, P. SPSS survival manual. A step by step guide to data analysis using IBM SPSS [Book Review]. Aotearoa N. Z. Soc. Work 2014, 26, 92. 
137. McNeish, D.; An, J.; Hancock, G.R. The thorny relation between measurement quality and fit index cutoffs in latent variable models. J. Personal. Assess. 2018, 100, 43-52. [CrossRef]

138. Ta, A.; Prybutok, V. A mindful product acceptance model. J. Decis. Syst. 2018, 27, 19-36. [CrossRef]

139. Fornell, C.; Larcker, D.F. Evaluating structural equation models with unobservable variables and measurement error. J. Mark. Res. 1981, 18, 39-50. [CrossRef]

140. Hair, J.F., Jr.; Sarstedt, M.; Ringle, C.M.; Gudergan, S.P. Advanced Issues in Partial Least Squares Structural Equation Modeling; Sage Publications: Newbury Park, CA, USA, 2017.

141. Hu, L.-t.; Bentler, P.M. Fit indices in covariance structure modeling: Sensitivity to underparameterized model misspecification. Psychol. Methods 1998, 3, 424. [CrossRef]

142. Al-Jinini, D.K.; Dahiyat, S.E.; Bontis, N. Intellectual capital, entrepreneurial orientation, and technical innovation in small and medium-sized enterprises. Knowl. Process. Manag. 2019, 26, 69-85. [CrossRef]

143. Danneels, E.; Vestal, A. Normalizing vs. analyzing: Drawing the lessons from failure to enhance firm innovativeness. J. Bus. Ventur. 2020, 35, 105903. [CrossRef]

144. Gelderen, M.V. Entrepreneurial autonomy and its dynamics. Appl. Psychol. 2016, 65, 541-567. [CrossRef]

145. DiVito, L.; Bohnsack, R. Entrepreneurial orientation and its effect on sustainability decision tradeoffs: The case of sustainable fashion firms. J. Bus. Ventur. 2017, 32, 569-587. [CrossRef]

146. Kallmuenzer, A.; Strobl, A.; Peters, M. Tweaking the entrepreneurial orientation-performance relationship in family firms: The effect of control mechanisms and family-related goals. Rev. Manag. Sci. 2018, 12, 855-883. [CrossRef]

147. Christensen, C.M.; McDonald, R.; Altman, E.J.; Palmer, J.E. Disruptive innovation: An intellectual history and directions for future research. J. Manag. Stud. 2018, 55, 1043-1078. [CrossRef]

148. Schulze-Krogh, A.C.; Calignano, G. How Do Firms Perceive Interactions with Researchers in Small Innovation Projects? Advantages and Barriers for Satisfactory Collaborations. J. Knowl. Econ. 2019, 1-23. [CrossRef]

149. Grashof, N.; Hesse, K.; Fornahl, D. Radical or not? The role of clusters in the emergence of radical innovations. Eur. Plan. Stud. 2019, 27, 1904-1923. [CrossRef]

150. Levine, D.S.; Sichelman, T. Why Do Startups Use Trade Secrets. Notre Dame L. Rev. 2018, 94, 751. [CrossRef]

151. Lie, H.T. Trade Secrets and Lead Time Advantages-Understanding Innovation Appropriation Mechanisms. SSRN Electron. J. 2018. [CrossRef]

152. Acosta, M.; Coronado, D.; Ferrandiz, E.; Marin, M.R.; Moreno, P.J. Patents and Dual-use Technology: An Empirical Study of the World's Largest Defence Companies. Def. Peace Econ. 2018, 29, 821-839. [CrossRef]

153. Hair, J.F., Jr.; Hult, G.T.M.; Ringle, C.; Sarstedt, M. A Primer on Partial Least Squares Structural Equation Modeling (PLS-SEM); Sage publications: Newbury Park, CA, USA, 2016.

154. Zhao, X.; Lynch, J.G., Jr.; Chen, Q. Reconsidering Baron and Kenny: Myths and truths about mediation analysis. J. Consum. Res. 2010, 37, 197-206. [CrossRef]

155. Varadarajan, R. Fortune at the bottom of the innovation pyramid: The strategic logic of incremental innovations. Bus. Horiz. 2009, 52, 21-29. [CrossRef]

156. Amewu, S.; Asante, S.; Pauw, K.; Thurlow, J. The economic costs of COVID-19 in sub-Saharan Africa: Insights from a simulation exercise for Ghana. Eur. J. Dev. Res. 2020, 32, 1353-1378. [CrossRef]

157. Danquah, M.; Schotte, S.; Sen, K. COVID-19 and Employment: Insights from the Sub-Saharan African Experience. Indian J. Labour Econ. 2020, 63, 23-30. [CrossRef]

158. Bamfo, B.A.; Kraa, J.J. Market orientation and performance of small and medium enterprises in Ghana: The mediating role of innovation. Cogent Bus. Manag. 2019, 6, 1605703. [CrossRef] 